BALTICA Volume 27 Number 2 December 2014 : 75-92

doi: 10.5200/baltica.2014.27.18

\title{
A comparative case study of subglacial bedforms in northern Lithuania and south-eastern Iceland
}

\author{
Valentinas Baltrūnas, Richard I. Waller, Vaidotas Kazakauskas, \\ Stasys Paškauskas, Valentas Katinas
}

Baltrūnas, V., Waller, R. I., Kazakauskas, V., Paškauskas, S., Katinas, V., 2014. A comparative case study of subglacial bedforms in northern Lithuania and south-eastern Iceland. Baltica, 27 (2), 75-92. Vilnius. ISSN 0067-3064.

Manuscript submitted 30 August 2014 / Accepted 4 November 2014 / Published online 10 December 2014

(C) Baltica 2014

\begin{abstract}
This paper aims to compare the dynamics of the subglacial environment as determined by an analysis of the structure and sedimentology of both Pleistocene and modern glacial deposits. Investigations focused on subglacial sediments in areas of streamlined relief in northern Lithuania (Ruopiškiai megascale subglacial lineations - MSGL) and south-eastern Iceland (drumlinised terrain exposed by the recent retreat of Skeiðarárjökull glacier). Sedimentological analyses involved granulometry, till macrofabrics, and the anisotropy of magnetic susceptibility (AMS) of micro-clasts. Comparative investigations of subglacial bedforms exposed at Ruopiškiai and Skeiðarárjökull highlighted differences in their formation and post-genetic transformation. In both cases, their initiation was associated with ice advance and subglacial sediment deformation. However, subsequent dynamics were different.
\end{abstract}

Keywords $\bullet$ subglacial environment $\bullet$ drumlin $\bullet$ till $\bullet$ magnetic susceptibility

$\square$ Vaidotas Kazakauskas (kazakauskas@geo.lt), Valentinas Baltrūnas, Stasys Paškauskas, Valentas Katinas, Nature Research Centre, Institute of Geology and Geography, Akademijos Str., 2, LT-08412 Vilnius, Lithuania; Richard I. Waller, School of Physical and Geographical Sciences, William Smith Building, Keele University, Keele, Staffordshire ST5 5BG, UK

\section{INTRODUCTION}

In common with other areas formerly glaciated by ice sheets, Lithuania is characterised by extensive regions of streamlined topography with low-relief and elongate bedforms measuring up to $15-20 \mathrm{~km}$ in length. They are mostly composed of till. Whilst Lithuanian landforms composed of glacigenic deposits have been thoroughly investigated, this streamlined relief has received relatively little attention. Numerous hypotheses for their genesis have been advocated within the literature with previous researchers referring to them as: (1) drumlins (Doss 1910; Hausen 1913; Mortensen 1924; Čepulytè 1956), (2) glacial meltwater erosion landforms (Mikalauskas, Mikutienè 1971), (3) marginal moraine ridges (Basalykas 1965) or (4) flutings (Gaigalas 1997; Gaigalas, Marcinkevičius 1982). The consequent lack of clear diagnostic features to aid their identification within Pleistocene settings has hampered their precise geological mapping in Lithuania. The study by Gaigalas, Marcinkevičius (1982) is worth special mention as it was the first study to use drilling data to aid reconstructions of glaciodynamic conditions in North Lithuanian relief based on the orientation and angle of the long axes of macro clasts.

Studies of this kind in the neighboring countries (Latvia, Estonia, Byelorussia, and Poland) are more numerous (Rattas, Kalm 2001; Zelčs, Dreimanis 1997; Zelčs, Markots 2004; Głębicki, Marks 2009; Matveyev et al. 1988). In other countries, the process of drumlinisation and related landforms have been investigated for some time, yet their deeper structural and genetic analysis has only been undertaken in the last decade. The special issue "Drumlins and subglacial landforms and processes" of the international journal "Sedimentary Geology" (No 232) contains a selection of papers presented at the VII International Drumlin Symposium (in May 2009) and is very 
valuable in this respect. In his introduction, Knight (2010a) outlines the significance of drumlins as a key subglacial bedform, provides a brief history of drumlin research, and identifies the major themes of subglacial research, namely mapping and morphometry, sedimentary and ice-bed processes, and glacier dynamics. He noted that studies over the preceding decades contain a similar message: namely that the subglacial environment is difficult to access and as a result many of its dynamic processes are unknown.

In this regard, investigations of subglacial bedforms near modern glaciers in Iceland (Johnson et al. 2010, Waller et al. 2008, Schomacker et al. 2006, Boulton 1987; Krüger 1987;), Sweden (Møller 2010), Antarctica (Smith et al. 2007; King et al. 2009; Rabassa 1987), and Switzerland (van der Meer 1983) are very important. Special attention should be paid to the investigations of actively forming subglacial bedforms in West Antarctica (Smith et al. 2007; King et al. 2009) and the recently exposed active drumlin field of Múlajökull (Iceland) where more than 50 drumlins was identified beyond the glacier's current margin (Johnson et al. 2010). These papers provide an insight into the subglacial conditions in which these subglacial bedforms are created.

The process of drumlinisation varies in terms of its intensity between different parts of the subglacial environment. It also generates a variety of landforms at different spatial scales, ranging from flutes, to drumlins and drumlinised ridges, through to megadrumlins and mega-scale glacial lineations (MSGLs) (Brodzikowski, van Loon 1991; Clark 1993; Bennett, Glasser 2009; Evans 2009; Knight 2010 a ,b; Spagnolo et al. 2010; Piotrowski et al. 2004). Numerous theories for drumlin (subglacial bedform) formation have been advocated. These were summarised into five classes by J. Menzies in 1984, but there are currently two key competing hypotheses (Benn, Evans 1998; Clark et al. 2009; Shaw 2010). Boulton's (1987) glacial hypothesis (direct erosion and/or deposition by ice or by a subglacial deforming bed create glacial bedforms) and Shaw's (2002) meltwater (megaflood) hypothesis (erosion and/or deposition by subglacial sheet floods create meltwater bedforms). The first hypothesis (Boulton's subglacial sediment deformation) remains the predominant working hypothesis for most current investigations.

The methodology of our research is generally based on an analysis of: (1) the structure and sedimentology of the drumlins, (2) data on macro clast orientation and dip, and (3) data on the anisotropy of magnetic susceptibility (AMS) of micro clasts. A study by Gentoso et al. (2012) suggests that the AMS method can be used to reconstruct former ice-flow directions. Investigations of thick, relatively homogeneous basal tills exposed in the drumlins and flutes of the Weedsport drumlin and flute field in New York State demonstrated that the anisotropy of magnetic susceptibility (AMS) and pebble fabrics were consistently oriented parallel to the streamlined bedforms. One of the objectives of this research is to undertake a comparative analysis of the data derived from clast macro fabrics with that derived from the AMS analysis of micro clasts.

The aim of this study is to compare the dynamics of the subglacial environment as revealed by an analysis of the structure of glacial sediments associated with both Pleistocene and modern glaciers. Two objectives were accomplished to achieve this aim: (1) investigation of the topography and sedimentological characteristics of subglacial bedforms in both Lithuania (Ruopiškiai) and in Iceland (Skeiðarárjökull), and (2) comparative analysis of the data on macro clasts orientation and dip and anisotropy of magnetic susceptibility (AMS) of micro clasts.

\section{STUDY SITES}

The study is based around the examination of streamlined subglacial bedforms in two contrasting environments: (1) Pleistocene megalineations situated near Ruopiškiai village (Biržai Distric) in northern Lithuania and, (2) modern-day drumlins exposed by recent retreat of Skeiðarárjökull in south-eastern Iceland (Fig. 1).

\section{Ruopiškiai megalineations: geomorphological and geological background}

The study area in Lithuania is located within the Vabalninkas field of mega-scale glacial lineations (further-MSGL) and is situated close to Ruopiškiai village in the Mūša-Nemunèlis Lowland. The smooth or wavy surface of the dominant loamy ground moraine plain in the northern part of Lithuania is in many places interspersed by low ridges and mounds oriented primarily in north-south directions. On most recent geomorphological map of Lithuanian (Guobyte 2002), these elevated landforms are mapped as "drumlin like-ridges". They are concentrated in three areas: Mažeikiai-Akmenè, Joniškèlis-Panevėžys and Biržai-Vabalninkas vicinities (Figs 1A and 2A, B). The area containing these ridges is truncated to the north by the Linkuva ice-marginal ridge generated by the Žiemgale ice lobe and in the south by ice-marginal formations of the Middle Lithuanian phase.

The glacial landscape of the study area was formed by the Mūša-Lèvuo ice lobe and only the north-eastern part was sculpted by the Middle Nemunèlis lobe (Mikalauskas, Mikutienè 1971). The rhythmically receding glacier created a complex of low lateral till formations (small hills and chains of low ridges). 


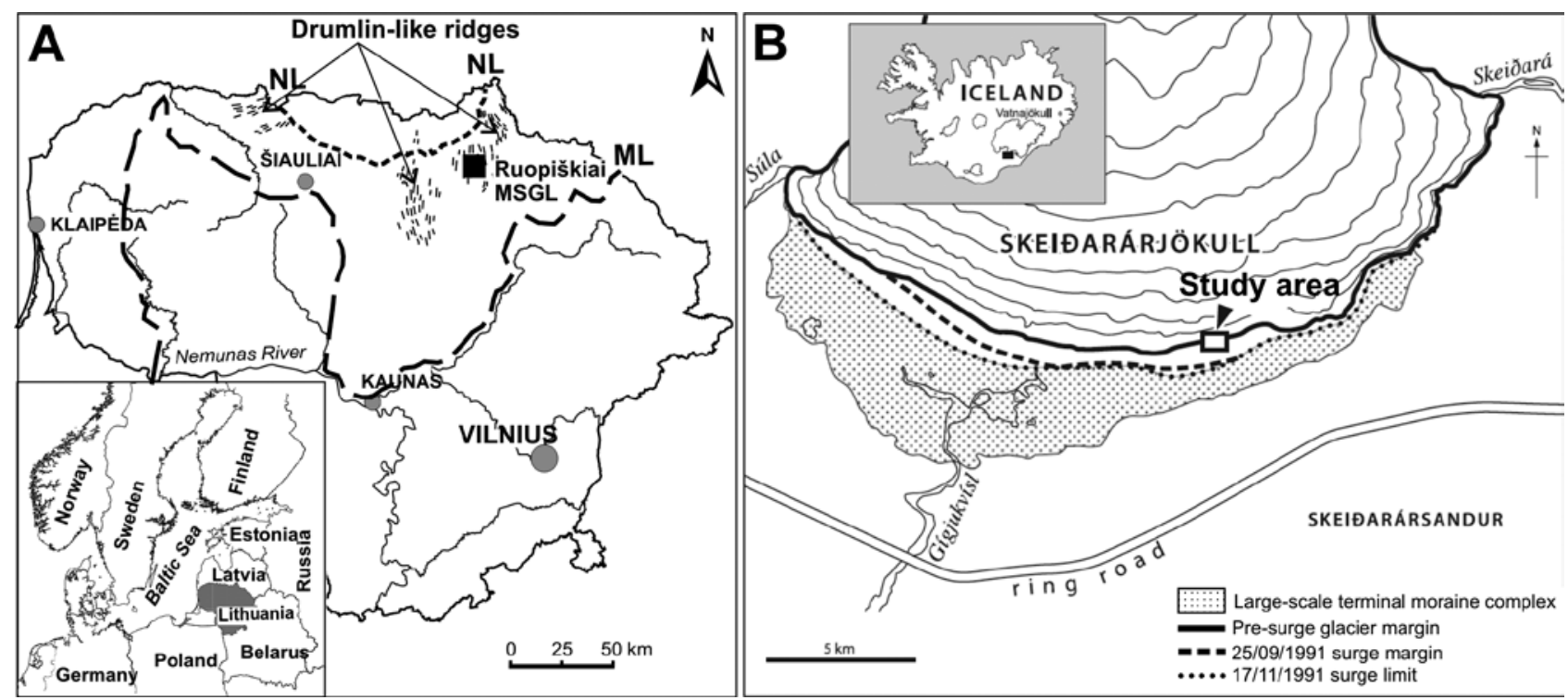

Fig. 1 Location of the study sites: A - Ruopiškiai MSGL in Lithuania; ML- limit of Middle-Lithuanian phase of Nemunas Glaciation, NL- limit of North-Lithuanian phase of Nemunas Glaciation (by Guobyte 2002); B - Skeiðarárjökull drumlins in Iceland (after Waller et al. 2008).
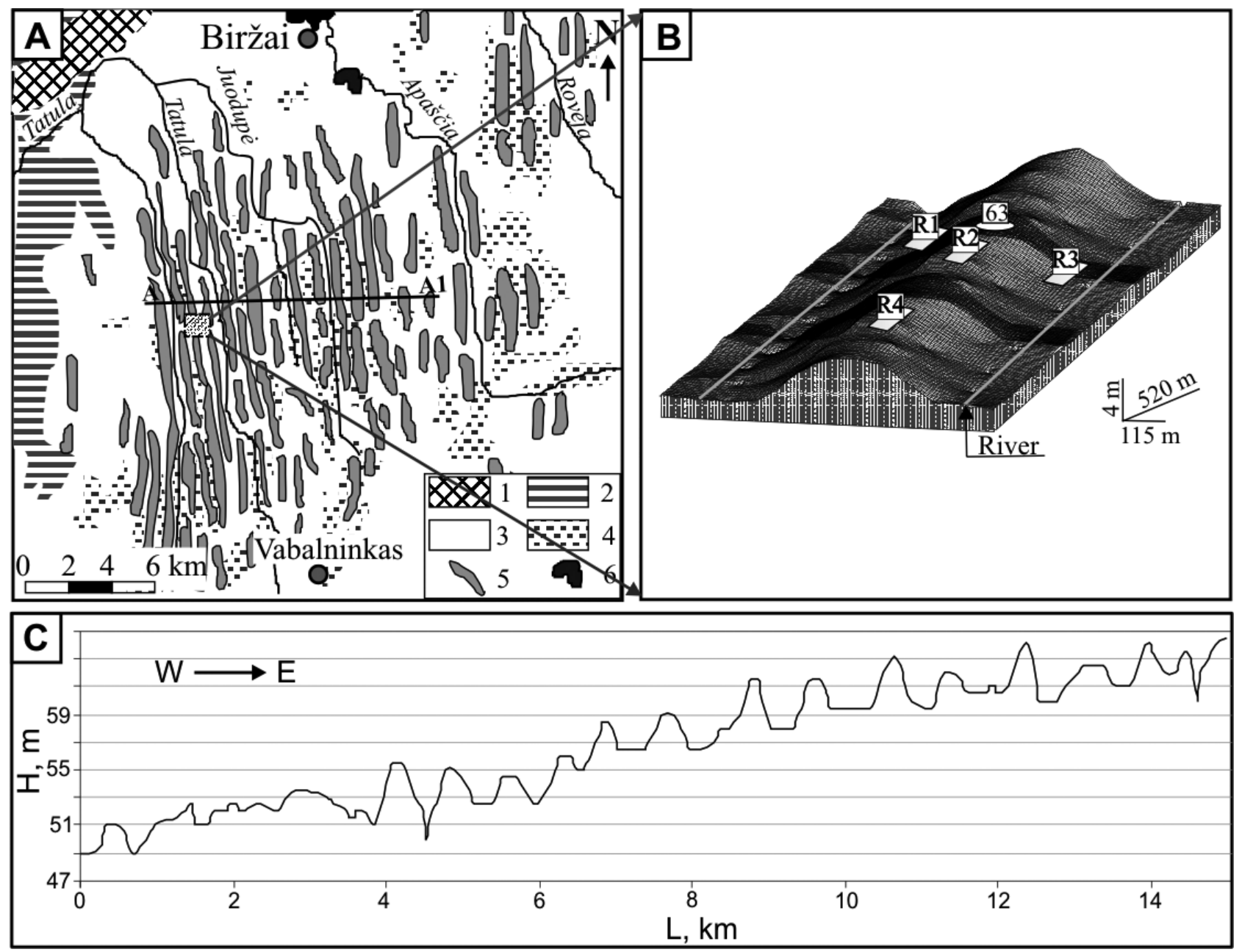

Fig. 2 Biržai-Vabalninkas MSGLs area (A) and location of the investigated Ruopiškiai MSGL: 1 - marginal formations; 2 - glaciolacustrine plain; 3 - till plain; 4 - bog deposits; 5 -drumlinoids; 6 - lake; A-A1 - topographic profile. (B) block diagram of the Ruopiškiai MSGL: pits R1-R4, 63 - borehole. (C) topographic profile of the Biržai-Vabalninkas MSGLs area north of the Ruopiškiai settlement. Compiled by S. Paškauskas and V. Kazakauskas. 


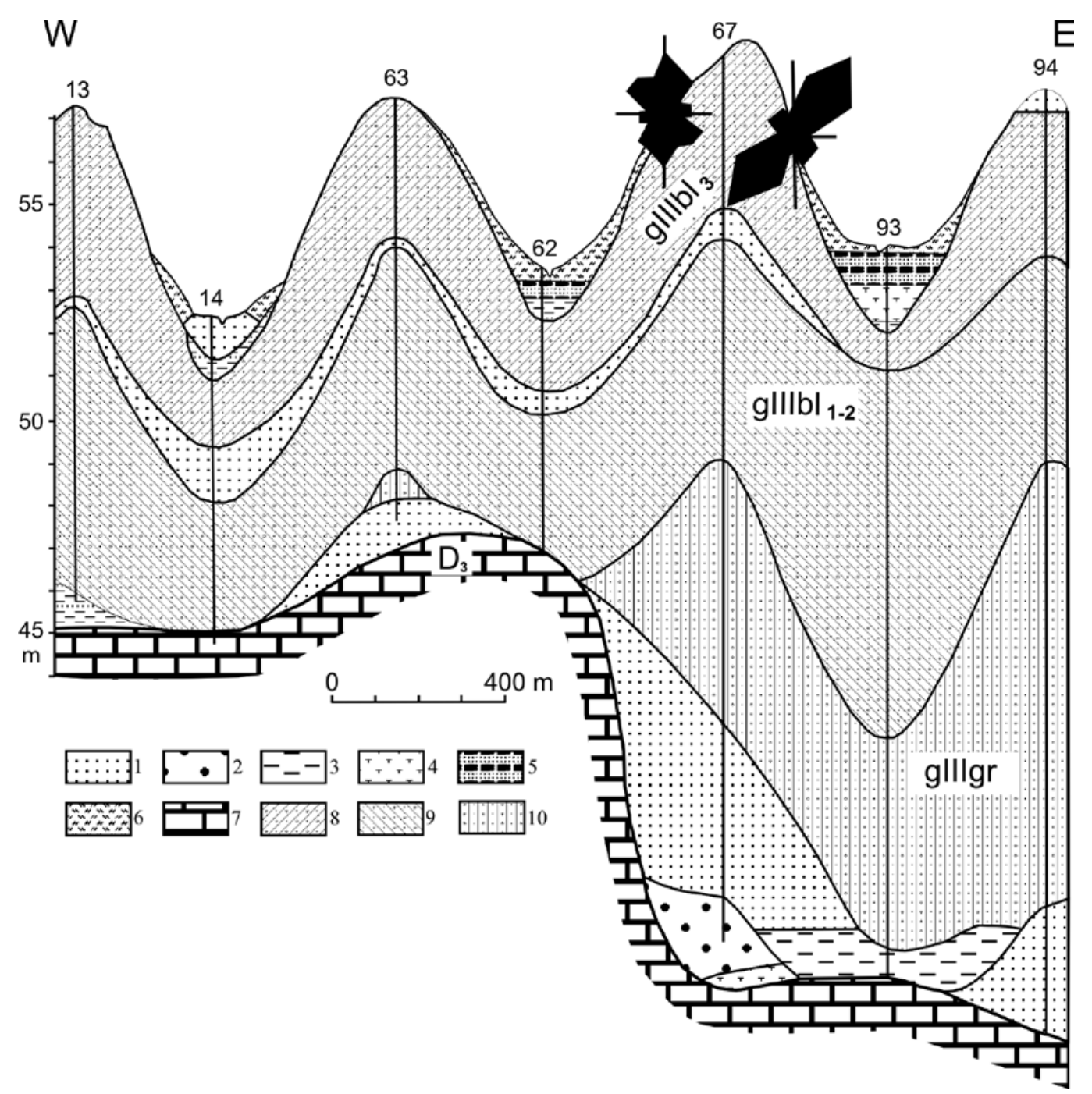

Fig. 3 Geological section of Biržai-Vabalninkas MSGLs area (from Gaigalas, Marcinkevičius 1982): 1 - sand, 2 - gravel, 3 - silt, 4 - gyttja, 5 - peat, 6 - colluvial deposits, 7 - dolomite and dolomitic marl, 8, 9 -till beds of the Baltija stage, 10 - till of the Grūda stage. The rose diagrams demonstrate the orientation of pebbles long axes.

Their relief was further accentuated by glaciofluvial erosion. Later, this relief was strongly affected by the impoundment of ice-dammed lakes. Resultant subaqueous mass flows resulted in a lowering and flattening of the relief whilst the isolated small hills merged into long ridges (Basalykas 1965). The absolute altitude of this undulating surface is $48-70 \mathrm{~m}$ (Fig. 2C).

The Quaternary strata comprise deposits of the Weichselian (locally termed Nemunas) glaciation that reach up to $20 \mathrm{~m}$ in thickness but which are limited to $2-5 \mathrm{~m}$ in thickness in areas strongly affected by glacial erosion (Gaigalas et al. 1971; Gaigalas, Marcinkevičius 1982). The glacigenic Pleistocene deposits (in the Ruopiškiai village environs) were deposited during the Grūda and Baltija stages of the Late Weichselian glaciation and are composed of a variable till sequence (Fig. 3).

This sequence comprises beds of red, brownish red, reddish brown, brown, greyish brown and grey tills occasionally separated by thin sand or silt interlayers. The thickness of the Quaternary deposits varies from $7-10 \mathrm{~m}$ to $22 \mathrm{~m}$. They overlie the uneven sub-Quaternary surface which dips steeply to the north. The sub-Quaternary surface is composed of dolomite, dolomite marl and dolomite powder of Tatula and Istra beds. The main part of the Quaternary deposits is composed of the Upper Pleistocene Weichselian tills deposited during the East, South and Middle Lithuanian phases of the Baltija Stage of the Nemunas Glaciation. The geological section shows undulating till layers of the Baltija Stage on the eroded Grūda till surface (Gaigalas, Marcinkevičius 1982).

The internal structure of the MSGLs was investigated in the northern part of the Middle Lithuanian Plain, in one of the largest areas of MSGLs in the vicinity of Biržai-Vabalninkas which occupies an area of $>500 \mathrm{~km}^{2}$. This MSGLs field overlies the so-called Kupiškis-Biržai pre-Quaternary elevation, which dips towards the northwest. 

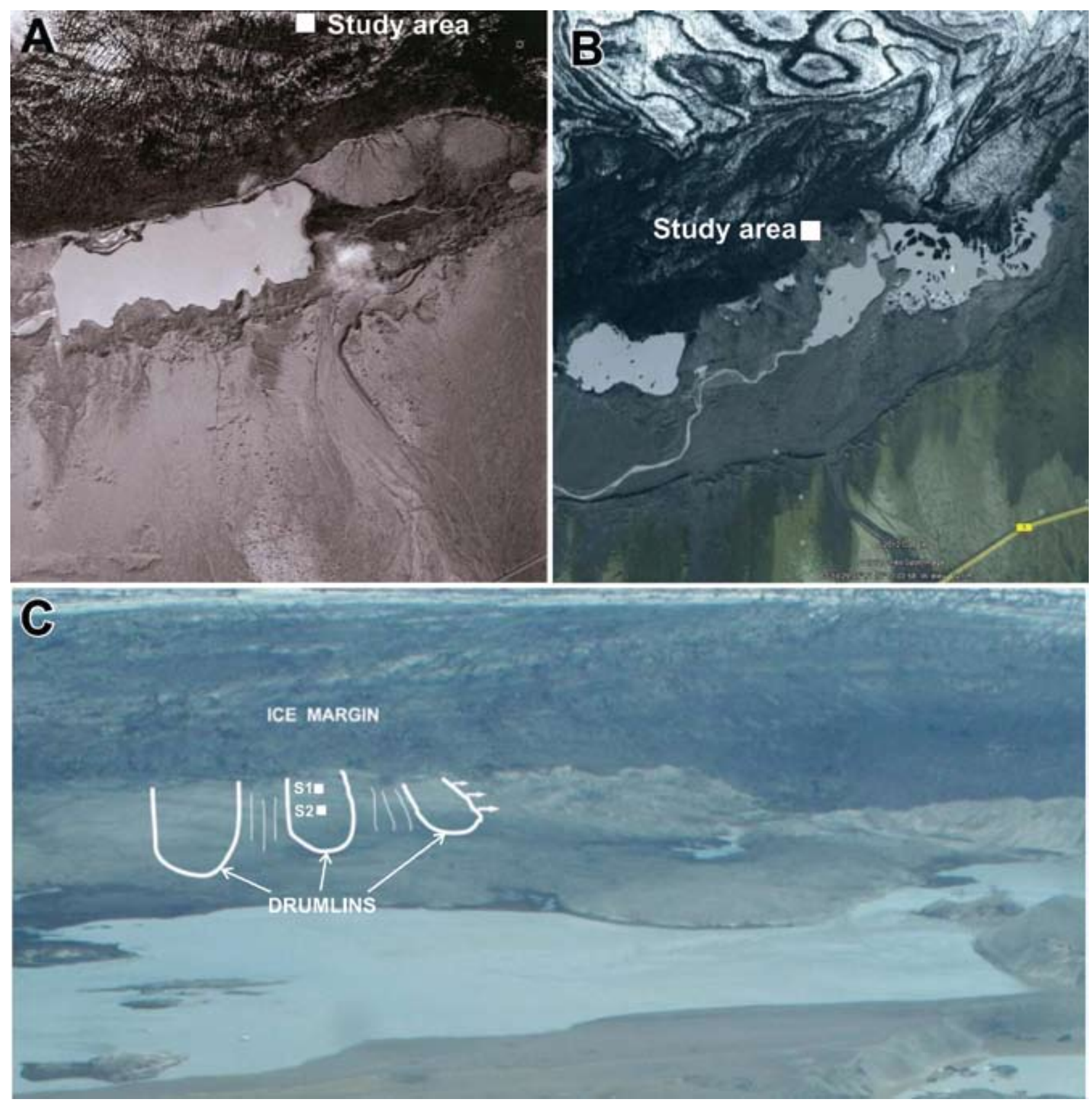

Fig. 4 Situation at the Skeiðarárjökull glacier edge: A) in 1992 (after the surge of 1991), B) in 2007 (squares stand for the study sites in 2011-2012), C) detailed situation of studied drumlins with fluted surface between them according to the Skeiðarárjökull situation in August 10, 2011 (B - photo from Google Earth, C - photo by R. I. Waller 2011).

The MSGLs area is composed of a complex of elongated mound-shaped ridges oriented in meridional and submeridional directions (azimuth $346-360^{\circ}$ ). The length of these ridges varies from 0.8 to $9 \mathrm{~km}$ (on the average $2.0-3.5 \mathrm{~km}$ ). The width of the ridges varies from 200 to $600 \mathrm{~m}$ (the average of $390 \mathrm{~m}$ ). The spacing between the parallel ridges is $890 \mathrm{~m}$ on average. The ridges are orientated in a north-south direction and are mostly 3-4 m but occasionally up to $6 \mathrm{~m}$ in height (see Fig. 2C). The ridges are slightly asymmetric: their western slopes are longer (average length of $195 \mathrm{~m}$ ) than the eastern slopes (average length of $156 \mathrm{~m}$ ). The flat crests of the ridges are in- terspersed (in distance of $520 \mathrm{~m}$ on average) by recurring small lanceolate crests with relative altitude of $0.5-1 \mathrm{~m}$. Measured morphometric ratios (W/L) range from 0.05-0.13. Consequently, according to Muller's (1974) classification these landforms are linear in character (fluting and ridge type).

In many places (at Gulbinènai, Raičiunèliai, Sukioniai), the ridges are broken by small valleys (30-70 m wide) which join the hollows between ridges. These valleys are generally orientated from NE to SW or from SE to NW. Presumably they were incised by the outflow channels from ice-dammed proglacial lakes. We suggest that the original length 
of these ridges would have been about $15-20 \mathrm{~km}$ and therefore that these ridges comprise mega-scale glacial lineations.

\section{Geomorphological setting and development of the Skeiðarárjökull drumlin field}

The study area in Iceland is located at the margin of Skeiðarárjökull in south-eastern Iceland $(631570 \mathrm{~N}$, $171210 \mathrm{~W}$ ) which is one of the largest outlet glaciers draining the southern part of the Vatnajökull ice cap (see Fig. 1B). The glacier margin comprises a broad, $23 \mathrm{~km}$ wide lobe terminating on Skeiðarársandur - a large active outwash plain. While the glacier is known for large volcanically-induced jökulhlaups, the most recent of which occurred in November 1996, it also experiences glacier surges. The last surge occurred between March and November 1991 (Sigurðsson 1998) (Fig. 4).

It featured a two-stage glacier advance, initially of the central margin by c. $450 \mathrm{~m}$ (May-July) and subsequently of the western margin by up to $1 \mathrm{~km}$ (September-November), with an estimated speed of $9.4 \mathrm{~m} /$ day (Pálsson et al. 1992). The ice advance increased the glacier's area by $10 \mathrm{~km}^{2}$ (Pálsson et al. 1992). The surge has been attributed to a reorganization of the channelized, subglacial drainage system into a linked-cavity system (e.g. Kamb et al. 1985; Kamb 1987), with large-scale subglacial water storage being indicated by the delayed drainage of a jökulhlaup from the subglacial caldera Grímsvötn in September 1991, and the discharge of meltwater from numerous small outlets along the glacier margin, rather than the normal outlets into the Súla and Skeiðara rivers (Björnsson 1998). The surge induced highly turbulent floods from newly formed tunnel outlets (Pálsson, Vigfússon 1996; Van Dijk, Sigurðsson 2002) and an increase in the number of outlets in the west (Russell et al. 2001). Ice advance and a change in meltwater routing led to the formation of a distinctive ice-marginal landsystem characterized by subglacially-fed outwash fans, fan-deltas and a distinctive landform assemblage of surge moraines and englacially-fed outwash fans (Van Dijk 2000a, b, 2002; Van Dijk, Sigurðsson 2002). The formation of these closely-spaced englacial outlets and associated fans and the intercalation of pushed surge-moraine material and non-deformed fan sediments in the ice-marginal moraine-fan assemblage are considered diagnostic of the surge event (Van Dijk 2002).

The area that provides the focus for this article is located in the central part of the glacier margin (see Fig. 1B). Identification of the site's location (see Fig. 4) on geo-referenced aerial photographs taken on 22 August 1988 by Landmælingar İslands
(LMÍ) demonstrates that the area was proglacial prior to the surge and characterized by an apron of overlapping ice-contact fans. Comparison with georeferenced aerial photographs taken in 1992 (Fig. 4A) and 1996 (Fig. 4B) confirms that the site was subsequently overridden during the surge and that it remained ice-covered during the November 1996 jökulhlaup.

The results of previous investigations on the drumlins in adjacent area, carried out by our co-author R. I. Waller (Waller et al. 2008), showed that the landform-sediment assemblage of drumlins, flutes and crevasse-fill ridges at Skeiðarárjökull is a composite of rigid-bed and soft-bed processes that indicate a change in subglacial processes and conditions during the surge. The well-drained nature of the fan sediments and consequent high effective pressures and shear strengths resulted in a phase of rigid-bed conditions during the initial stages of the surge. Rapid erosion and sediment transport during this phase were key in the development of the drumlins, in terms of both drumlinisation of their stoss sides and re-deposition of the eroded material as a lee-side diamicton (Waller et al. 2008).

\section{METHODS}

The morphometric parameters of the MSGLs of Lithuania were determined by cartometric measuring made using topographic maps (1:10 000). This work was carried out using methods developed during previous investigations in Greenland (Baltrūnas et al. 2009).

The composition of the Ruopiškiai MSGL, the thickness and sedimentological characteristics of the depositional units as well as clast fabrics and samples for AMS were taken from excavated pits. The test pits were dug to a depth of 1.4-1.9 $\mathrm{m}$ in the western and eastern slopes and in the crest of the studied MSGL. The orientation and dip of the long axes of 50 elongate clasts were measured at 8 locations. Samples for grain size analysis were taken from the upper (at a depth of $0.7-1.0 \mathrm{~m}$ ) and lower $(1.2-1.8 \mathrm{~m})$ parts of the till bed.

Similar analysis of till was performed in the Skeiðarárjökull drumlin. The pits were dug to a depth of 1-1.4 $\mathrm{m}$ in the crest of the drumlin. One pit (excavated c. $100 \mathrm{~m}$ from the glacier margin) represented the frontal part of the drumlin and the second pit (excavated c. $120 \mathrm{~m}$ down glacier from the first pit) represented the middle part of the drumlin.

\section{Grain size and macrofabric analyses}

Grain-size analysis of the air-dried soil samples was conducted via dry sieving using a set of sieves from 
$5 \mathrm{~mm}$ to $0.125 \mathrm{~mm}$ and $1 / 3$ phi $(\Phi)$ interval. The sieving was conducted using a mechanical device (Fritsch Sieve Shaker "Analysette 3"). The distribution of the fine soil fraction $(<0.125 \mathrm{~mm})$ was determined using a Fritsch Laser Particle Sizer "Analysette 22" at the Open Access Centre of the Nature Research Centre
(Lithuania). The differentiation of particle size was performed on the Udden and Wentworth scale (Blott, Pye 2001).

The orientation and dip of the long axes of 50 clasts with elongation ratios of $\geq 3: 2$ was measured at 12 sites in the drumlins using a geological compass
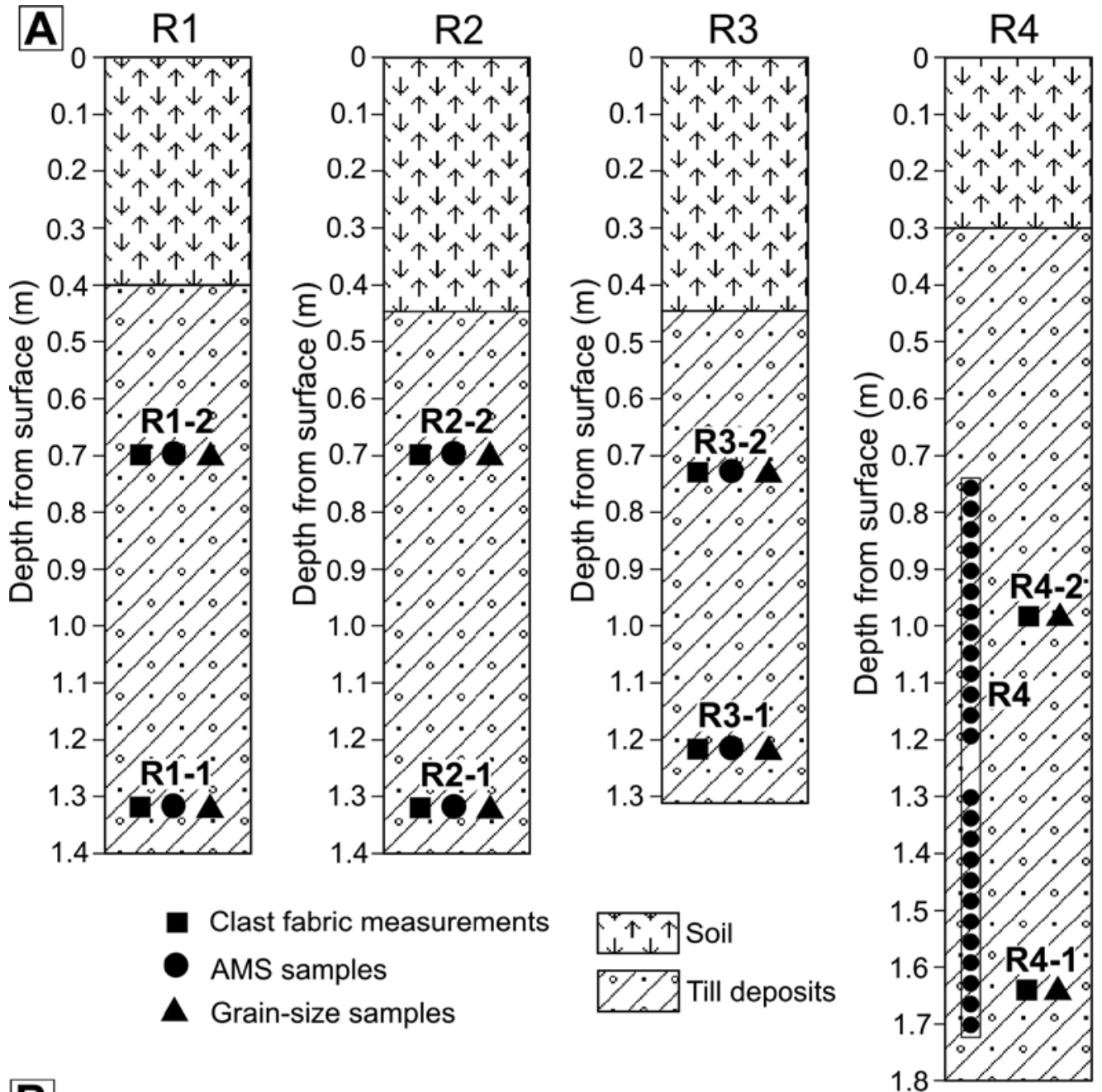

B

- Clast fabric measurements

- AMS samples

- Grain-size samples

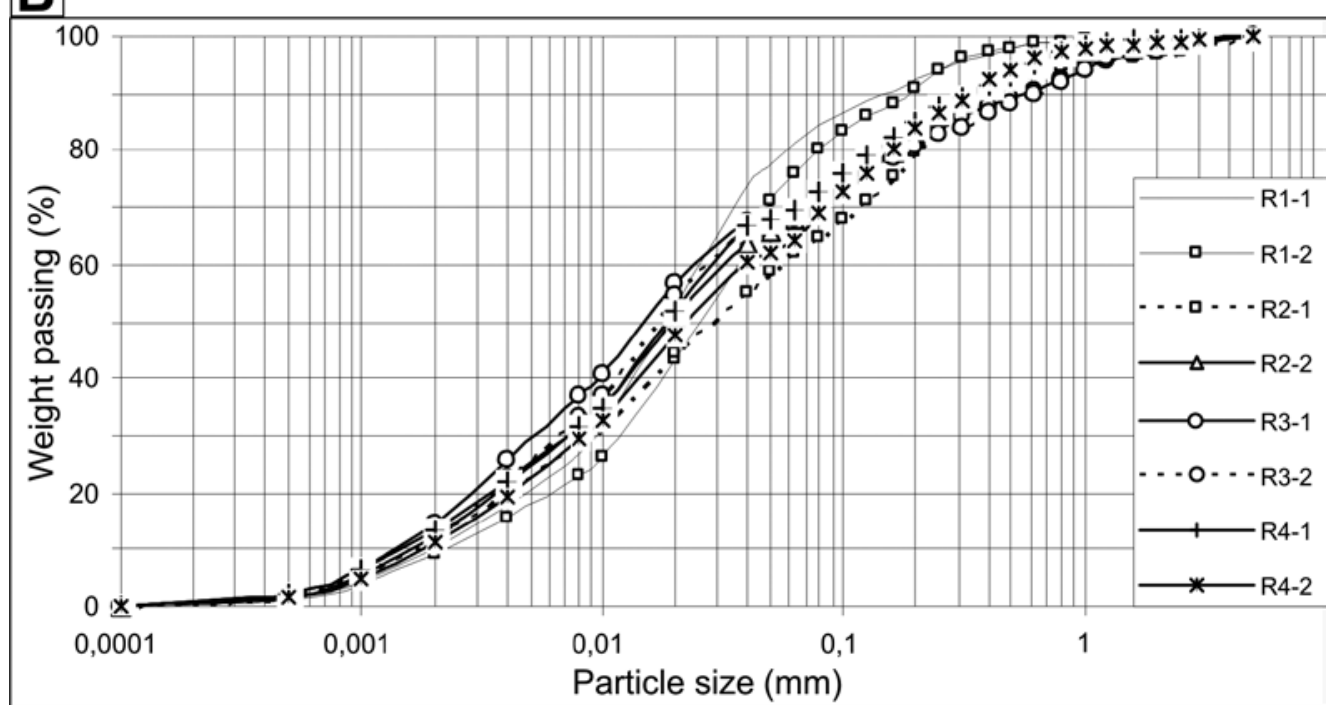

Fig. 5 (A) Investigated sections of the Ruopiškiai MSGL and (B) grain size distribution of till. See Fig. 2B for location. Compiled by V. Kazakauskas and S. Paškauskas. 
using the method outlined by A. Gaigalas (1979). Graphic stereograms were compiled taking into account the deviation of the magnetic field. The stereograms were compiled manually showing on them every measuring point. The dip of the long axes of clasts was estimated statistically. All measurements were summarized into three principal eigenvalues (Woodcock 1977). Fabric isotropy ( $\mathrm{I}=\mathrm{S} 3 / \mathrm{S} 1)$ and elongation indices $(\mathrm{E}=1-(\mathrm{S} 2 / \mathrm{S} 1))$ were subsequently calculated and used to plot the fabrics on ternary diagrams according to Benn (1994).

\section{Anisotropy magnetic susceptibility (AMS)}

The samples from the Ruopiškiai MSGL (Lithuania) were taken by pressing in special plastic boxescylinders (Natsuhara Giken Co.) from four investigation sites: 40 samples were taken from R1 site, 39 samples from R2, 40 samples from R3 and 34 samples from R4 sites (see Fig. 2 for location). Samples from the Skeiðarárjökull drumlin field (Iceland) were taken by pressing in special plastic boxescubes (ASC Scientific Co.) from two investigation sites: 70 samples (from three different parts of till layer) were taken from $\mathrm{S} 1$ site and 50 samples from S2 (from three different parts of till layer; see Fig. 4 for location).

AMS was measured with a MFK1-B kappabridge (AGICO) at the Open Access Centre of the Nature Research Centre (Lithuania). The AMS measurements were made along fifteen different directions (Jelinek 1977). The analysis of AMS data was performed using the Anisoft 4.2 software.
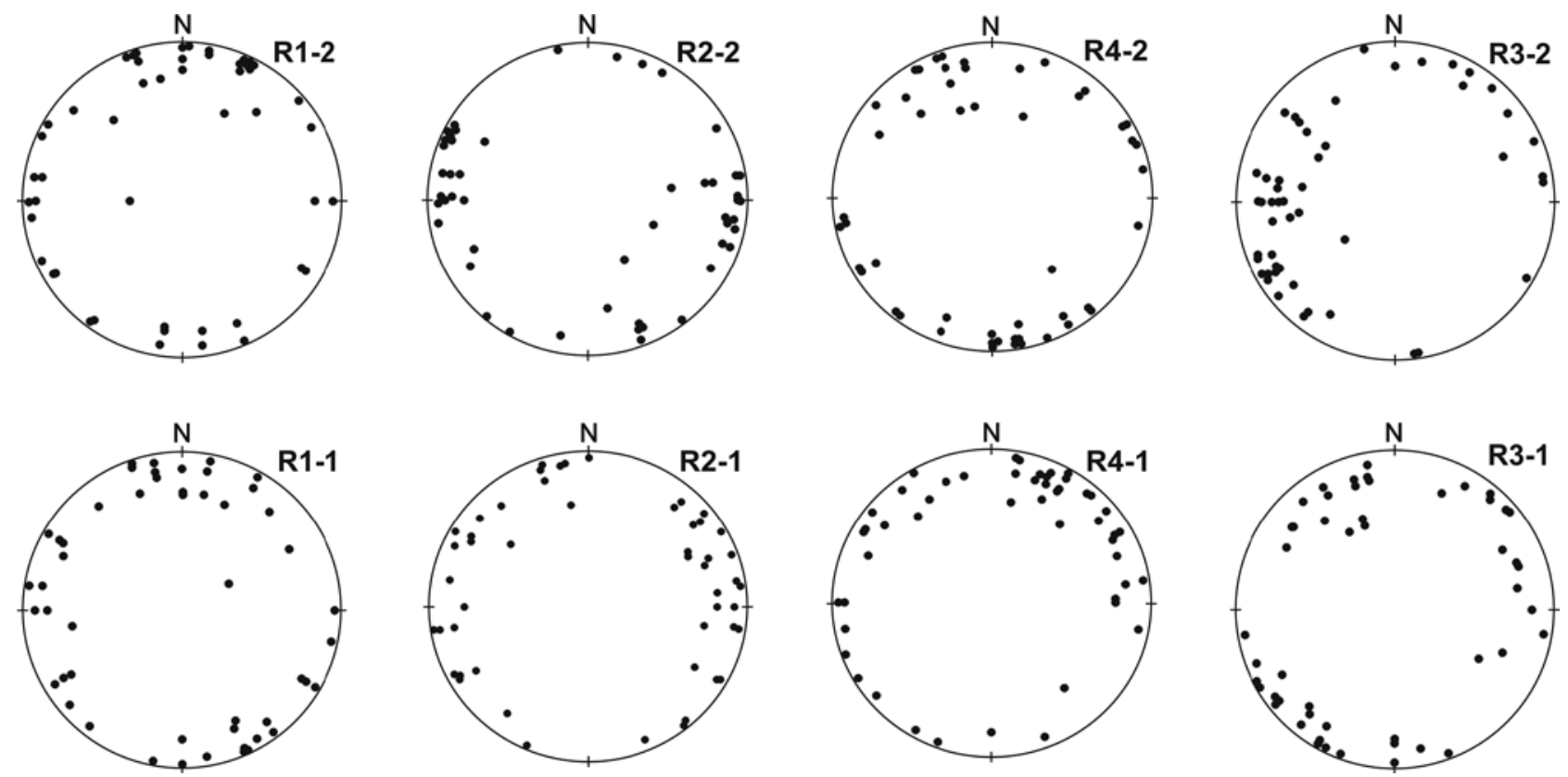

Fig. 6 Orientation of pebbles long axes in the investigated sites of Ruopiškiai MSGL. Compiled by V. Baltrūnas and V. Kazakauskas. 
Table 1 Summary of clast fabric data.

\begin{tabular}{|c|c|c|c|c|c|c|c|c|}
\hline \multirow{2}{*}{ Site } & \multirow{2}{*}{$\begin{array}{l}\text { Fabric } \\
\text { No. }\end{array}$} & \multirow{2}{*}{$\begin{array}{l}\text { Mean orien- } \\
\text { tation }\left(^{\circ}\right)\end{array}$} & \multirow{2}{*}{$\begin{array}{c}\text { Mean dip } \\
\left({ }^{\circ}\right)\end{array}$} & \multicolumn{3}{|c|}{ Eigenvalues } & \multirow{2}{*}{$\begin{array}{l}\text { Isotropy } \\
\text { index }\end{array}$} & \multirow{2}{*}{$\begin{array}{l}\text { Elongation } \\
\text { index }\end{array}$} \\
\hline & & & & $\mathrm{S} 1$ & S2 & S3 & & \\
\hline \multicolumn{9}{|c|}{ Ruopiškiai MSGL } \\
\hline \multirow{2}{*}{ Western slope of the MSGL } & $\mathrm{R} 1-1$ & 326.1 & 10.9 & 0.578 & 0.365 & 0.057 & 0.10 & 0.37 \\
\hline & $\mathrm{R} 1-2$ & 339.2 & 9.5 & 0.598 & 0.353 & 0.050 & 0.08 & 0.41 \\
\hline \multirow{4}{*}{ Crest of the MSGL } & R2-1 & 27.5 & 10.6 & 0.609 & 0.348 & 0.042 & 0.07 & 0.43 \\
\hline & R2-2 & 172.4 & 11.0 & 0.673 & 0.266 & 0.062 & 0.09 & 0.61 \\
\hline & R4-1 & 11.9 & 10.5 & 0.600 & 0.368 & 0.032 & 0.05 & 0.39 \\
\hline & R4-2 & 236.7 & 9.8 & 0.606 & 0.342 & 0.052 & 0.09 & 0.44 \\
\hline \multirow{2}{*}{ Eastern slope of the MSGL } & R3-1 & 287.4 & 12.9 & 0.571 & 0.362 & 0.067 & 0.12 & 0.37 \\
\hline & R3-2 & 275.6 & 15.6 & 0.647 & 0.302 & 0.051 & 0.08 & 0.53 \\
\hline \multicolumn{9}{|c|}{ Skeiðarárjökull drumlin } \\
\hline \multirow{2}{*}{ Frontal part of the drumlin } & $\mathrm{S} 1-2$ & 101.9 & 9.6 & 0.775 & 0.181 & 0.044 & 0.06 & 0.77 \\
\hline & $\mathrm{S} 1-3$ & 287.9 & 13.9 & 0.560 & 0.361 & 0.078 & 0.14 & 0.36 \\
\hline \multirow{2}{*}{ Middle part of the drumlin } & $\mathrm{S} 2-2$ & 153.3 & 11.5 & 0.674 & 0.270 & 0.056 & 0.08 & 0.60 \\
\hline & S2-3 & 158.0 & 11.0 & 0.657 & 0.298 & 0.045 & 0.07 & 0.55 \\
\hline
\end{tabular}

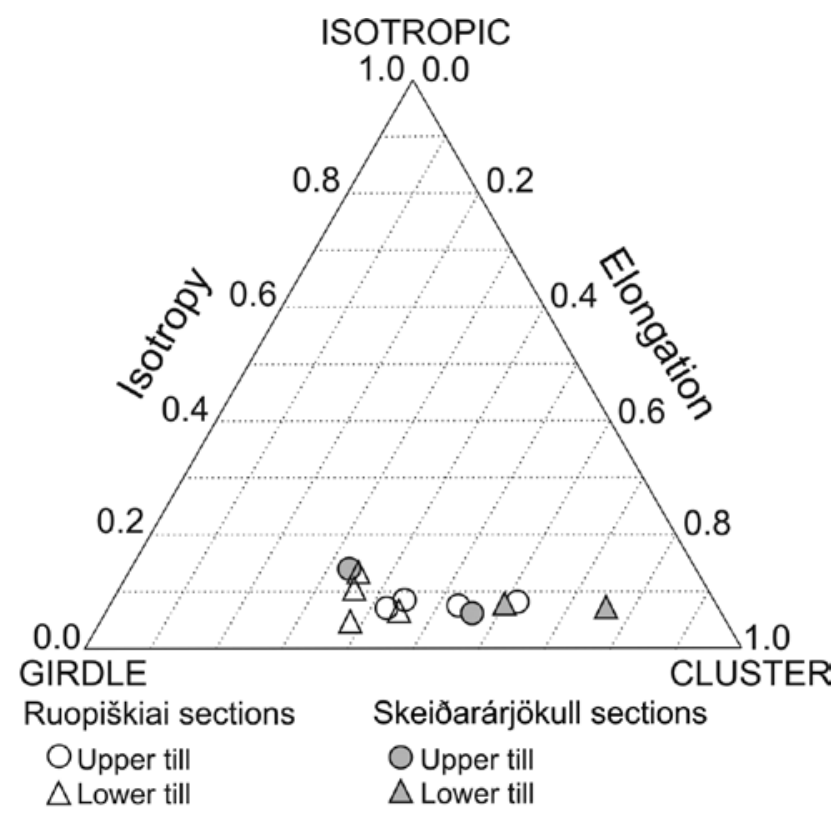

Fig. 7 Ternary diagram summarising all the clast fabric data recorded at all investigated sites (plotted according to Benn 1994). Compiled by S. Paškauskas.

loam up to $0.1-0.2 \mathrm{~mm}$ thick. This is covered by a thin layer of fine-grained clayey-sands that contains sporadic pebbles.

A slight increase in clay content $(1.2-2.3 \%)$ and a concomitant small decrease in the sand content (1.4-6.5\%) in the lower part of the till layer can be observed in all the sites (see Fig. 5B). The statistical parameters of grain size composition of the studied deposits show that the upper and lower parts are almost identical. Small differences can be observed only between the deposits of the eastern and western slopes. In the western slope, the average diameter of the particles is $0.07-0.08 \mathrm{~mm}$ whereas in the eastern slope it is $0.18-0.19 \mathrm{~mm}$.

\section{Till macrofabrics analysis of the Ruopiškiai MSGL}

The majority of the macroclasts are composed of sedimentary rocks with crystalline rocks (magmatic and metamorphic) accounting for a considerably smaller proportion. The sediments are predominated by the Devonian dolomites $(20.8-50 \%)$ and Silurian and Ordovician limestone (15.9-42\%). The portions of sandstone, other limestone and marl are smaller. The content of crystalline rocks ranges from 9-20.3\%.

The meridional orientation of clasts in the lower part of till layer is dominant in the western slope (pit R1) of the MSGL. More than $44 \%$ of all measured pebbles are orientated N-S (Fig. 6). Their average dip is $10.9^{\circ}$ yet the dip of about $30 \%$ of them does not exceed $2^{\circ}$. The greatest dip $\left(12-14^{\circ}\right)$ is characteristic of pebbles orientated in N, NE and $\mathrm{W}$ directions. The eastern orientation is almost horizontal $\left(<2^{\circ}\right)$. In the upper part of the till bed the orientation of pebbles is the same as in the deeper part only with even higher concentration of pebbles orientated N-S (56\%). The average dip is slightly lower $\left(9.5^{\circ}\right)$ and varies little with orientation.

Two clast fabrics recorded from the lower and upper parts of the till bed on the western slope of the MSGL (R1-1 and R1-2) display mean orientations (NNW-SSE) approximately parallel to the long-axis orientation of the MSGL and similar low mean dip values (around $10^{\circ}$ ) (Table 1). Both fabrics show low isotropy indices and intermediate elongation indices indicating medium strength fabrics (Fig. 7).

The majority of the clasts in the lower parts of the till unit exposed in the eastern slope of the Ruopiškiai MSGL (R3) are orientated SW-NE (38\%) and N-S $(28 \%)$ (see Fig. 6). The average dip is $12.9^{\circ}$ but the dip in the dominant directions is slightly lower than 
the average value. In the upper part of the till unit, the orientation of pebbles is almost the same with prevailing directions of SW-NE (32\%) and W-E (40\%). Thus, the long axis of almost half of the measured pebbles is perpendicular to the MSGL's crest. Their average dip is $15.6^{\circ}$. The largest dip is characteristic of pebbles with a $\mathrm{W}$ orientation.

Two clast fabrics recorded from the lower and upper parts of the till unit on the eastern slope (R3-1 and R3-2) display mean orientations close to NW-SE (287.4 $4^{\circ}$ in the lower till and $275.6^{\circ}$ in the upper till) and slightly higher mean dip values than the western slope. Both clast fabrics show low isotropy and elongation values generally similar to those of the western slope with the exception of the fabric R3-2 from the upper till. Low isotropy indices and intermediate elongation indices similarly result in medium strength fabrics (see Table 1, Fig. 7).

The crest of the MSGL (R2) is characterized by a well-developed fabric with approximately $70 \%$ of the macroclasts being orientated in E-W and NESW directions. This fabric does not change significantly with depth. The average dip also remains almost the same from bottom $\left(1.6^{\circ}\right)$ to top $\left(11.0^{\circ}\right)$ although there are some differences relating to orientation. The measurements in pit R4 on the top of the MSGL do not show the same similarity between the upper and lower till. In the lower till, pebbles are orientated meridionally yet the azimuths are widely dispersed. In the upper till, the dispersion of directions is not as distinct because almost half (46\%) of the macroclasts are orientated $\mathrm{N}-\mathrm{S}$. The average dips and their variation by directions (see Fig. 6) are comparable with those observed in pit R2. The only difference is that the dip of the clasts in the lower till is higher. In pit R4, the dip was higher than in the upper till layer.

Four clast fabrics recorded from the lower and upper parts of till on the crest of the MSGL (R2-1, R2-2, R4-1 and R4-2) show mean orientations close to the

Table 2 AMS parameters of Ruopi kiai MSGL: (mean magnetic susceptibility $\left(\mathrm{K}_{\mathrm{m}}\right)$, magnetic lineation (L), magnetic foliation $(\mathrm{F})$, anisotropy degree $(\mathrm{P})$, shape parameter $(\mathrm{T})$, long axis $\left(\mathrm{K}_{\max }\right)$ and short axis $\left(\mathrm{K}_{\min }\right)$.

\begin{tabular}{|c|c|c|c|c|c|c|c|c|}
\hline Site & $\mathrm{N}$ & $\mathrm{K}_{\mathrm{m}}\left(10^{-6} \mathrm{SI}\right)$ & $\mathrm{L}$ & $\mathrm{F}$ & $\mathrm{P}$ & $\mathrm{T}$ & $\mathrm{K}_{\max }\left({ }^{\circ}\right)$ & $\mathrm{K}_{\min }\left({ }^{\circ}\right)$ \\
\hline $\mathrm{R} 1-2$ & 20 & $9,98 \mathrm{E}-5$ & 1.008 & 1.016 & 1.025 & 0.325 & $109 / 8$ & $220 / 70$ \\
\hline $\mathrm{R} 1-1$ & 20 & $7.09 \mathrm{E}-5$ & 1.009 & 1.018 & 1.027 & 0.347 & $84 / 20$ & $212 / 59$ \\
\hline $\mathrm{R} 2-2$ & 19 & $1.66 \mathrm{E}-4$ & 1.007 & 1.039 & 1.047 & 0.698 & $69 / 25$ & $264 / 64$ \\
\hline $\mathrm{R} 2-1$ & 19 & $1.51 \mathrm{E}-4$ & 1.009 & 1.040 & 1.049 & 0.627 & $70 / 26$ & $263 / 64$ \\
\hline $\mathrm{R} 3-2$ & 20 & $6.35 \mathrm{E}-5$ & 1.005 & 1.009 & 1.015 & 0.283 & $49 / 6$ & $289 / 77$ \\
\hline $\mathrm{R} 3-1$ & 20 & $4.54 \mathrm{E}-5$ & 1.006 & 1.003 & 1.009 & -0.380 & $178 / 1$ & $260 / 44$ \\
\hline $\mathrm{R} 4 / \mathrm{A}$ & 24 & $1.50 \mathrm{E}-4$ & 1.020 & 1.027 & 1.048 & 0.163 & $311 / 2$ & $218 / 63$ \\
\hline $\mathrm{R} 4 / \mathrm{B}$ & 10 & $1.48 \mathrm{E}-4$ & 1.022 & 1.035 & 1.057 & 0.220 & $33 / 7$ & $247 / 82$ \\
\hline
\end{tabular}
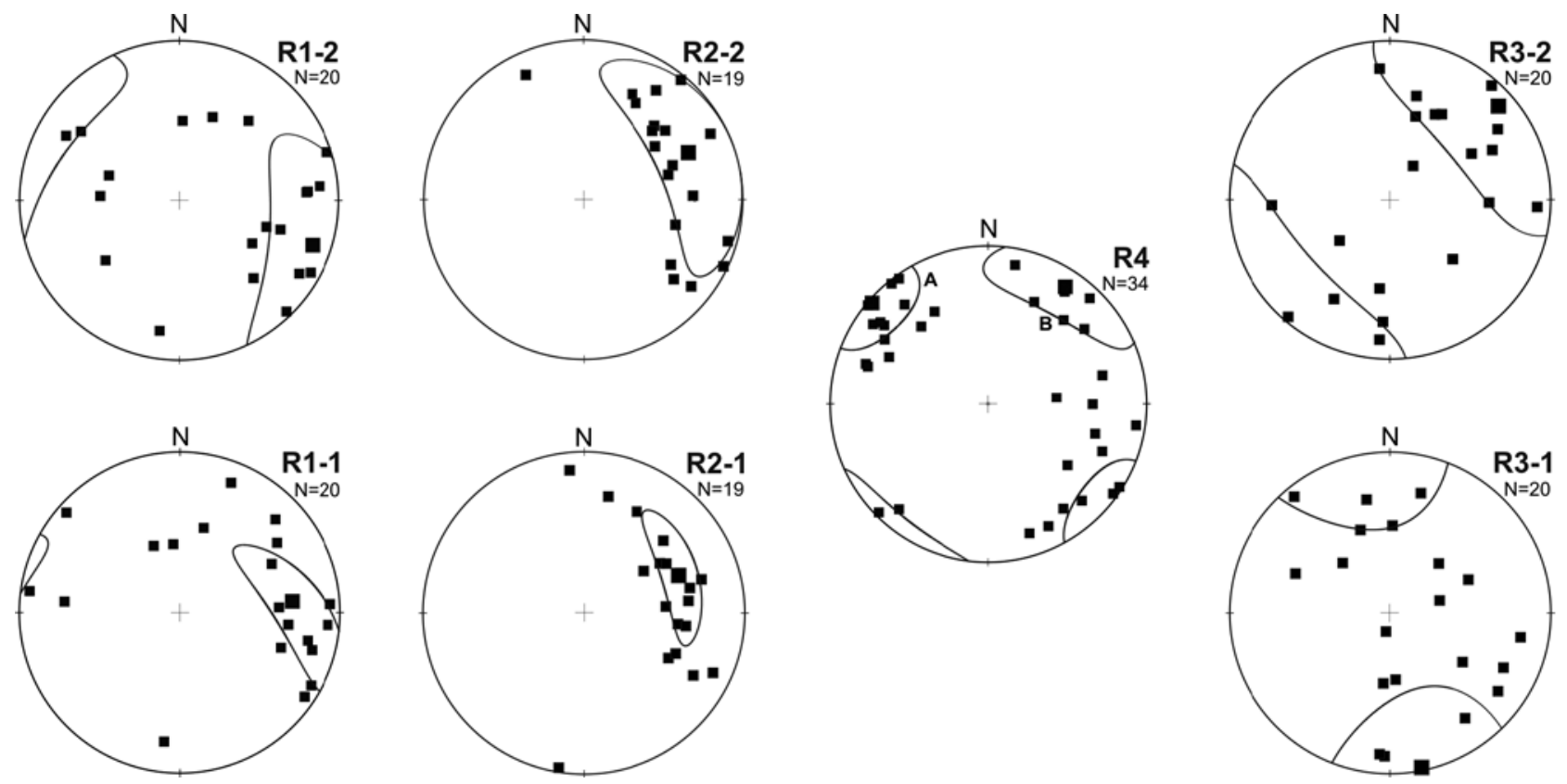

Fig. 8 AMS directional results of Ruopiškiai investigated sites. Small symbols represent specimen eigenvectors; high symbols represent mean eigenvectors, square $-\mathrm{K}_{\max }$. Compiled by V. Katinas. 
long-axis orientation (N-S) of the MSGL (with the exception of R4-2 fabric form upper till oriented SWNE) and similar (around $10^{\circ}$ ) low mean dips (see Table 1). All fabrics investigated on the crest of the MSGL display low isotropy indices and low to medium elongation indices with the exception of the R2-2 fabric which shows the highest (0.61) elongation value of all the measured fabrics. All eight clast fabrics from different parts of the Ruopiškiai MSGL are characterized by relatively low isotropy values and medium elongation values, indicating medium strength fabrics that plot midway between the girdle and cluster apices of the ternary fabric diagram (see Fig. 7).

\section{Results of AMS microfabrics analysis of till of the Ruopiškiai MSGL}

Microfabric samples for AMS microfabric analysis were extracted from the same four sites (R1, R2, R3 and R4) used for macrofabric and grain-size distribution analyses.

The mean AMS long axis orientation of samples from the western slope of the MSGL (R1-1 and R1-2) are almost perpendicular (W-E) to the long-axis orientation of the MSGL with mean plunges $\leq 20^{\circ}$ (Table 2, Fig. 8), which deviate rather significantly from the average macroclast long-axis orientation of this site (WNW-ESE, with dips around $14^{\circ}$ (see Table 1).
Two AMS microfabrics recorded from the eastern slope of the MSGL (R3-1 and R3-2) display rather different mean orientations: R3-1 microfabric show meridional orientation and R3-2 show NE-SW direction with low dips (see Table 2, Fig. 8). These orientations deviate rather significantly from the average macroclast long-axis orientation of this site (NNWSSE), plunging around $10^{\circ}$ (see Table 1).

Both AMS microfabrics recorded from the crest of the MSGL (R2-1, R2-2) display similar mean orientations of NE-SW with dips around $25^{\circ}$. The R4 section of till deposits was not divided into lower and upper part for the AMS sampling and the microfabrics of this section reflect the orientation of the whole till layer. So, AMS microfabric of the R4 section display two different mean orientations (NW-SE and NESW) with low plunges (see Table 2, Fig. 8). These orientations deviate rather significantly from the average macroclast long-axis orientation of this site (close to meridional orientation with dips around $10^{\circ}$ ).

\section{Skeiðarárjökull drumlin investigation data}

\section{Geomorphological characteristics}

In the study area, three adjacent ridges orientated parallel to direction of glacier flow were distinguished in the ice-marginal surface topography (see Figs $4 \mathrm{C}$ and
A
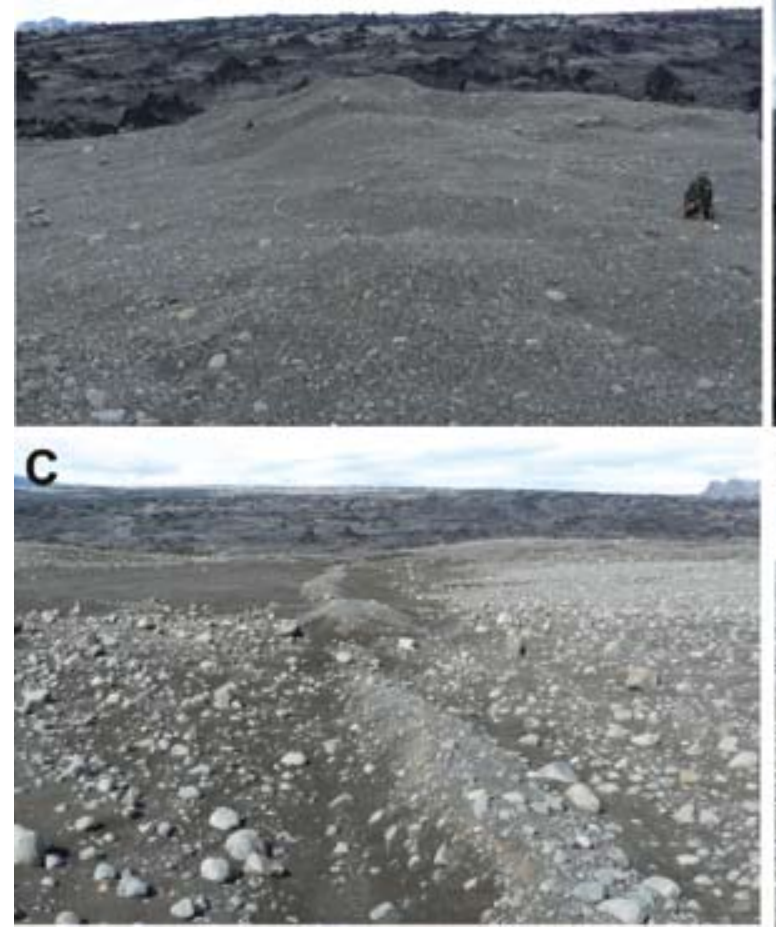
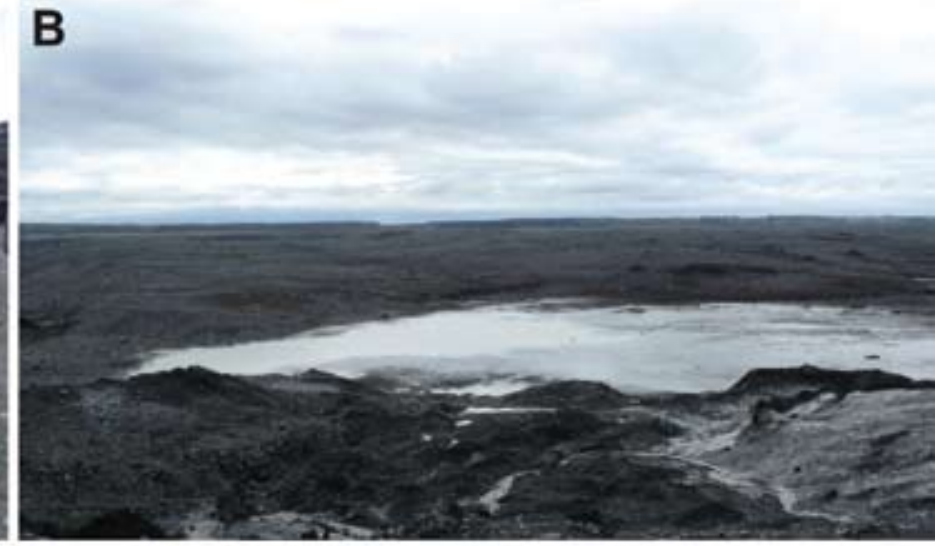

D

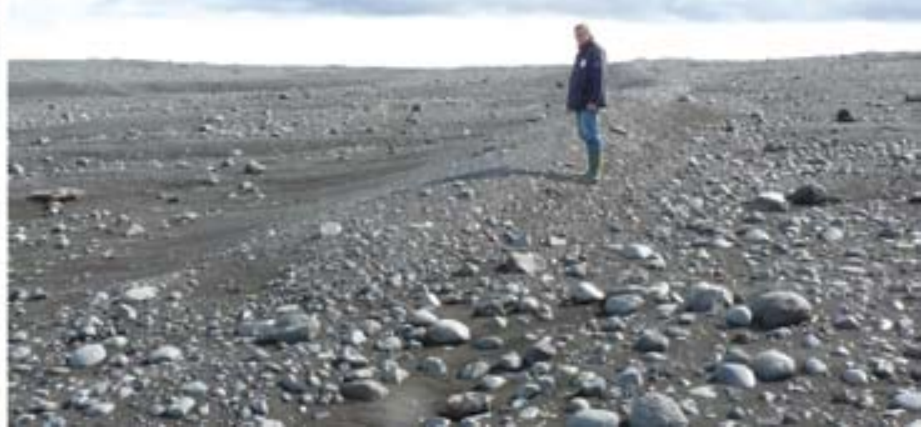

Fig. 9 Skeiðarárjökull drumlin on the distal side (A), on upglacier side (B) and a low surface with flutes between them (C, D). Photo by V. Baltrūnas 2012. 
9). The ridges were separated from the ice margin by depressions that contain sedimentological evidence of former ice-marginal lakes. They also displayed evidence of former incision by small proglacial meltwater channels. These linear ridges have been interpreted as having formed subglacially and are classified as drumlins. At the time of the studies, these glacial landforms were located 50-200 $\mathrm{m}$ from the retreating glacier margin. They were separated from the retreating ice margin by small depressions and small areas of hummocky moraine containing stagnant ice blocks.
The eastern slope of the eastern drumlin is steep and eroded. It merges into a more low lying area of hummocky moraine (see Fig. 9). A narrow zone of rugged morainic relief with dead ice and a well-defined glacier margin occurs north of the drumlins. At the terminal part of the eastern drumlin, the glacier terminates in a proglacial lake. The shapes and sizes of drumlins are comparable and therefore only one was chosen for morphometric measurement and analysis of the internal composition. The studied drumlin was about $380 \mathrm{~m}$ length and $80-120 \mathrm{~m}$ width. The average
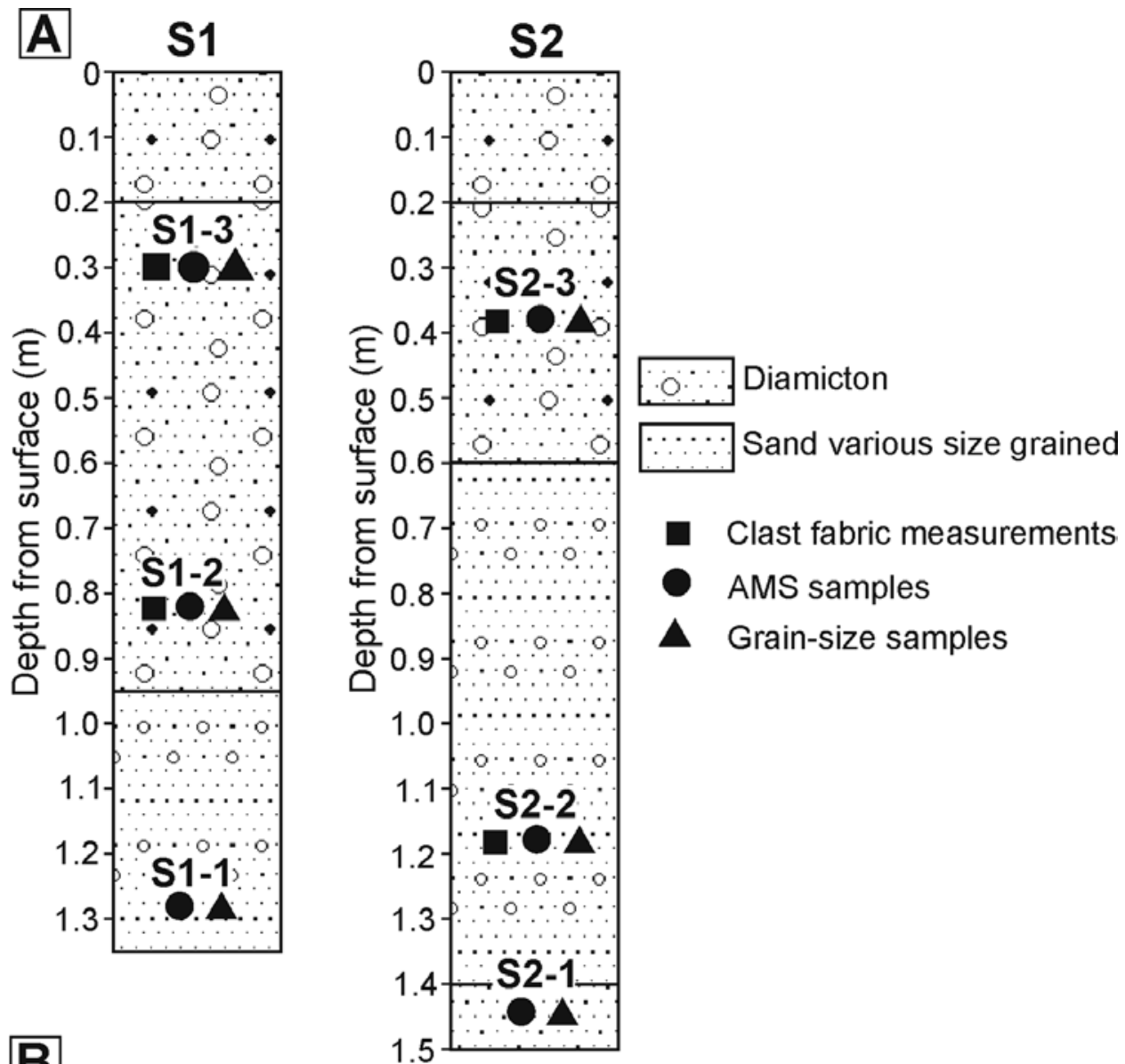

B

1.5

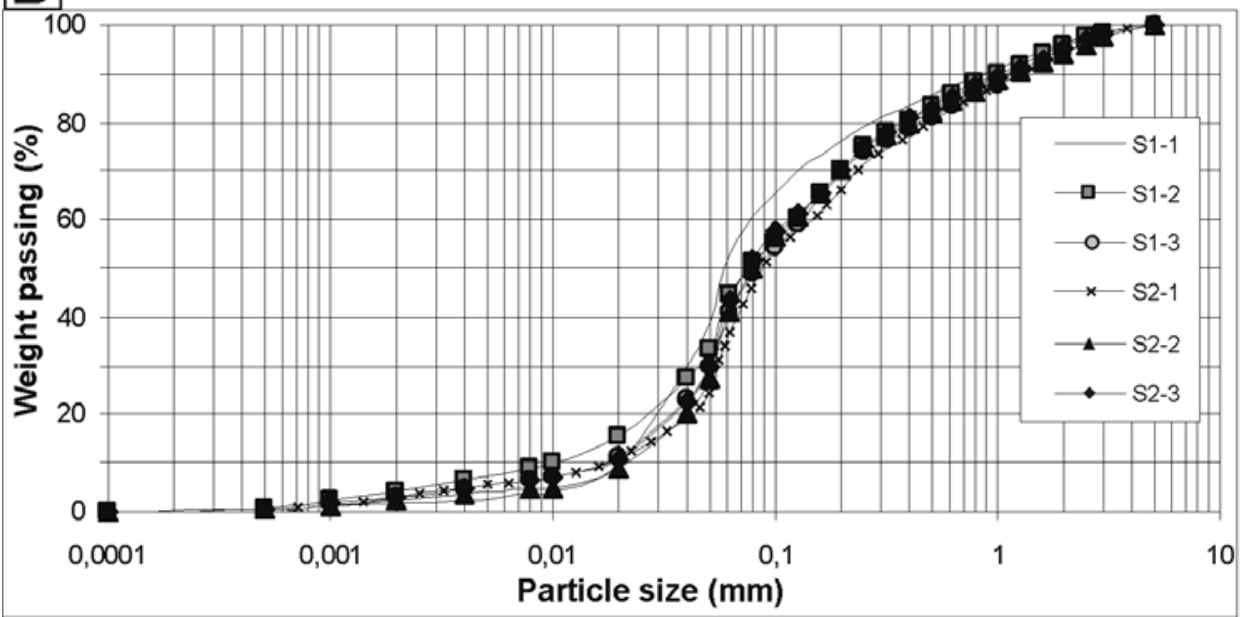

Fig. 10 (A) Sections and descriptions of test pits S1 and S2 (see Figs 1B and 4C for location) in the Skeiðarárjökull drumlin with marked sampling sites and (B) grain size composition of till. Compiled by V. Kazakauskas and S. Paškauskas. 
relative height ranged from 3.4-3.6 to $4 \mathrm{~m}$. The crest of the drumlin features a flat oval surface 10-20 m wide and the lateral flanks of the drumlin have slope angles of $3.5^{\circ}$ and $4.1^{\circ}$. The ratio between the length and the width (3.8) indicates a low degree of elongation. Based on Muller's (1974) classification of glacigenic relief, according to the ratio width/length $(0.26)$ the drumlin can be described as "long ovoid".

The drumlin surface is overlain by smaller surface features. These include small $0.3-0.6 \mathrm{~m}$ high ridges up to 3-5 $\mathrm{m}$ in width and up to $6-10 \mathrm{~m}$ in length. Similar but slightly longer (up to a few metres in length) parallel ridges were also observed. These are thought to represent subglacial crevasse-fill ridges and flutes as previously described by Waller et al. (2008).

\section{Grain size composition}

Two test pits were excavated on the crest of the investigated drumlin: one located in an ice-proximal location (S1) and the other located in the middle part of the drumlin (S2) $100 \mathrm{~m}$ down glacier (see Fig. 4C). The pit in the middle part of the drumlin displays some evidence of stratification that is illustrated by slight variations in colour, clast content and variations in grain size. The till in pit $\mathrm{S} 2$ can be divided into three different beds (Fig. 10A): (1) a friable till unit up to $0.2 \mathrm{~m}$ in depth, (2) a compact till unit $(0.2-1.4 \mathrm{~m}$ depth) that is more sandy in its lower part (0.6-1.4 m depth) and, (3) a sandy-pebble diamicton layer below $1.4 \mathrm{~m}$ depth. The grain size composition of these units is similar. The content of some fractions is almost identical in all three units (Fig. 10B). The sediments in the middle part (S2) of the drumlin
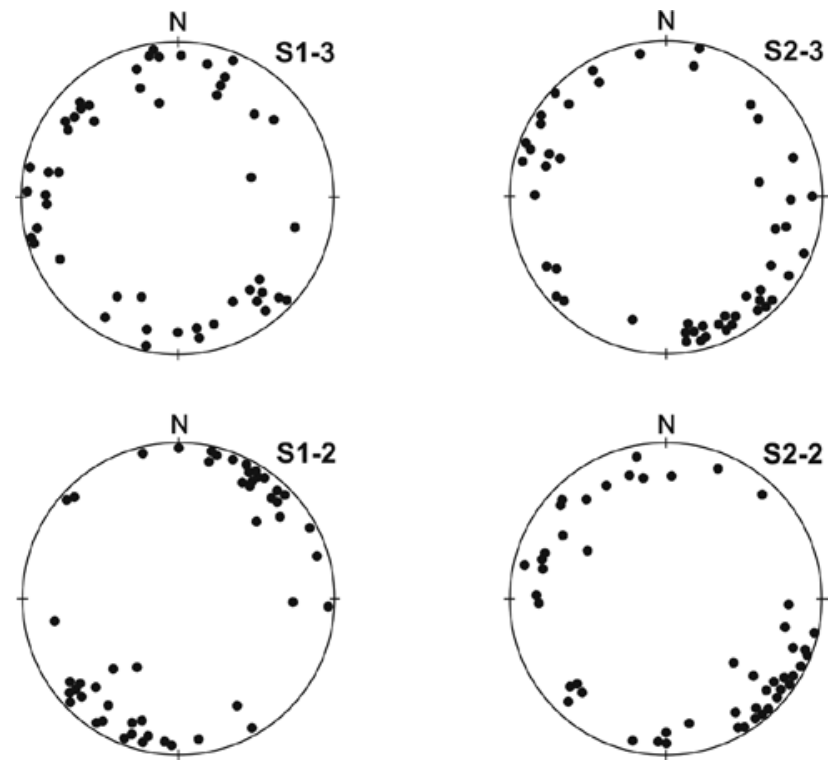

Fig. 11 Orientation of pebbles long axes in the both test pits of Skeiðarárjökull drumlin. See Figs $1 \mathrm{~B}$ and $4 \mathrm{C}$ for location of the macrofabric measurements sites. Compiled by V. Baltrūnas and V. Kazakauskas. contain a very small amount $(2.5-3.2 \%)$ of the finest $(<0.002 \mathrm{~mm})$ clay-size material and a low concentration of pebbles $(6.9-7.9 \%)$. The dominant fractions are sand (63.0-67.5\%) and silt (21.5-26.8\%). Silt is mainly concentrated in the upper till $(26.8 \%)$ and its concentration diminishes with depth. The concentration of sandy material varies in the opposite direction increasing in concentration with depth.

The sedimentological variations in the proximal pit (S1) (see Fig. 10A) are similar to those observed within the middle pit (S2). Again it displays an upper till unit (0.2-0.6 m depth), a lower lower till unit $(0.6-0.95 \mathrm{~m}$ depth) and a sandy layer $(0.95-1.35 \mathrm{~m}$ depth). The variations in the grain-size fractions are also similar. Clays account for $4.43 \%$ and pebbles for $5.5-8.3 \%$ (see Fig. 10B). Sands (55.7-62.0\%) and silt particles $(26.6-37.1 \%)$ are again dominant. In this part of the drumlin, the upper till is sandier than the lower ones whereas the latter is richer in silt particles whose amount increases from top to bottom. The average diameter of particles in the proximal part of drumlin varies from 0.29 to $0.39 \mathrm{~mm}$ and in its middle part from 0.35 to $0.40 \mathrm{~mm}$, i.e. it is composed of medium-grained sand which is coarser in the middle part. The composing material is poorly sorted.

\section{Till macrofabrics analysis}

Most of the macroclasts in the middle part of the drumlin (S2) are sub-meridionally orientated. The SE-NW direction (Fig. 11) is dominant in the lower (44\%) and upper till units (38\%). The distribution of clast orientations is similar in both tills. This is demonstrated by the negligible difference $\left(5.4^{\circ}\right)$ between the azimuths and the essentially identical variation coefficients of directions (0.48-0.49). The higher dips $\left(13.4^{\circ}\right)$ of clasts in the lower till unit show that it was more strongly affected by the receding glacier than the upper till $\left(8.8^{\circ}\right)$. The dip of clasts of various orientations ranges from $6.7-19^{\circ}$ yet the average orientation and dip in both till units (lower $11.5^{\circ}$; upper $11.0^{\circ}$ ) are essentially the same.

Two clast fabrics recorded from the lower and upper till units in the middle part of the drumlin (S2-2 and S2-3) display mean orientations similar NNW-SSE to the long-axis orientation of the drumlin and low mean dip values. Both fabrics display low isotropy indices and medium to high elongation indices, indicating quite strongly oriented fabrics (see Table 1, Fig. 11).

In the proximal part of the drumlin (S1), the dominant clast orientation is different to that in the distal (S2) part (see Fig. 11). The lower till is characterized by clasts with a sub-meridional orientation yet the dominant direction is different with $54 \%$ of clasts being orientated NE-SW. An additional $30 \%$ of clasts are orientated $\mathrm{N}-\mathrm{S}$. The implication is that the lower 
Table 3 AMS microfabric parameters of the glacigenic deposits comprising the Skeiðarárjökull drumlin: (mean magnetic susceptibility $(\mathrm{Km})$, magnetic lineation $(\mathrm{L})$, magnetic foliation $(\mathrm{F})$, anisotropy degree $(\mathrm{P})$, shape parameter $(\mathrm{T})$, long axis $\left(\mathrm{K}_{\max }\right)$ and short axis $\left(\mathrm{K}_{\min }\right)$.

\begin{tabular}{|c|c|c|c|c|c|c|c|c|}
\hline Site & $\mathrm{N}$ & $\mathrm{K}_{\mathrm{m}}\left(10^{-6} \mathrm{SI}\right)$ & $\mathrm{L}$ & $\mathrm{F}$ & $\mathrm{P}$ & $\mathrm{T}$ & $\mathrm{K}_{\max }\left({ }^{\circ}\right)$ & $\mathrm{K}_{\min }\left({ }^{\circ}\right)$ \\
\hline $\mathrm{S} 1-1$ & 20 & $2.20 \mathrm{E}-3$ & 1.004 & 1.002 & 1.006 & -0.295 & $12.4 / 49$ & $272 / 9$ \\
\hline $\mathrm{S} 1-2$ & 26 & $2.52 \mathrm{E}-3$ & 1.005 & 1.001 & 1.006 & -0.815 & $13 / 12$ & $232 / 74$ \\
\hline $\mathrm{S} 1-3$ & 25 & $3.03 \mathrm{E}-3$ & 1.005 & 1.001 & 1.006 & -0.452 & $16.4 / 9$ & $117 / 48$ \\
\hline $\mathrm{S} 2-1$ & 7 & $2.11 \mathrm{E}-3$ & 1.002 & 1.005 & 1.007 & 0.3 .18 & $336 / 43$ & $75 / 10$ \\
\hline $\mathrm{S} 2-2$ & 20 & $1.98 \mathrm{E}-3$ & 1.006 & 1.001 & 1.007 & -0.835 & $12 / 4$ & $274 / 63$ \\
\hline $\mathrm{S} 2-3$ & 23 & $2.73 \mathrm{E}-3$ & 1.005 & 1.001 & 1.006 & -0.550 & $8 / 6$ & $177 / 84$ \\
\hline
\end{tabular}
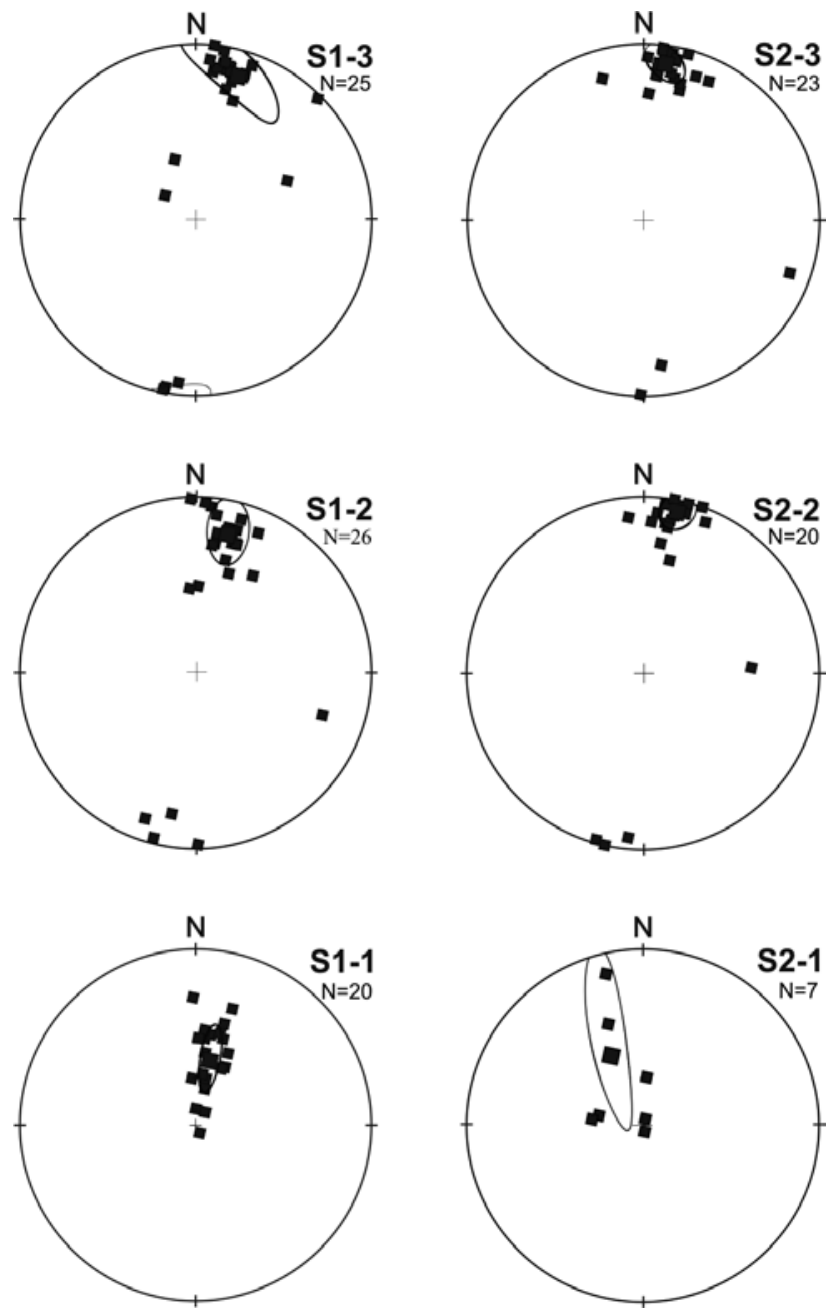

Fig. 12 AMS directional results of Skeiðarárjökull drumlin (S1, S2). Small symbols represent specimen eigenvectors; high symbols represent mean eigenvectors, square $-\mathrm{K}_{\max }$ See Figs $1 \mathrm{~B}$ and $4 \mathrm{C}$ for location of the AMS sampling sites. Compiled by V. Katinas.

till in this part of the drumlin was more strongly affected by glacially-induced shear stresses with a narrow range of directions between $\mathrm{N}-\mathrm{S}$ and NE-SW accounting for $84 \%$ of the measurements. The average dip of clasts in different orientations ranges from 2.0 $18.0^{\circ}$. The dominant N-S and NW-SE directions for the whole section (lower and upper till units) account for $38 \%$ and $68 \%$ of all measurements. The average dip for the entire dataset is $13.9^{\circ}$ although it is very slightly higher in the dominant orientation $\left(14.2^{\circ}\right)$. In contrast to the pattern displayed in the middle part of the drumlin, the upper and lower till layers are marked by greater differences in both clast orientation and average dip (dip difference of $4.3^{\circ}$ ).

Two clast fabrics recorded from the lower and upper parts of the till on the proximal part of the drumlin (S1-2 and S1-3) display low dip values and different mean orientations: NNE-SSW (fabric from the lower part S1-3) and WNW-ESE (fabric from the upper part S1-3). Both fabrics show low isotropy indices and medium to high elongation indices, indicating medium to high strength fabrics (see Table 1, Fig. 11).

All fabrics recorded from the Skeiðarárjökull drumlin and the Ruopiškiai MSGL generally display orientations that are sub-parallel to the long-axis orientation of the subglacial bedform. They also display low dips of $<16^{\circ}$. They are characterized by low isotropy values and medium to high elongation values, indicating generally medium strength fabrics that plot midway between the girdle and cluster apices of the ternary fabric diagram (see Fig. 7).

\section{AMS analysis}

The glacigenic units comprising the Skeiðarárjökull drumlin were investigated using the AMS method at two sites (S1, S2). Within six AMS microfabrics recorded from two sites ( $\mathrm{S} 1$ and $\mathrm{S} 2)$ on the crest of the drumlin, the mean AMS long axis orientations are similar (NNE-SSW or NNW-SSE) to the long-axis orientation of the drumlin and plunges are low (ranging from $4^{\circ}$ to $12^{\circ}$ ). Exceptions were the microfabrics recorded from sandy till layer at the bottom of the test pits that display the highest plunges: $43^{\circ}$ (S2-1) and $49^{\circ}$ (S1-1) respectively (Table 3 , Fig. 12).

\section{INTERPRETATION AND DISCUSSION}

The grain size analyses have demonstrated that the subglacial bedforms are composed of glacigenic materials with a broad range of sediment textures. The grain size varies from a few microns (clay, silt) to centimetres and decimetres in diameter (pebbles and solitary boulders). According to the grain size classification of clastic deposits (Gaigalas 1995), the material 
composing the Ruopiškiai MSGL is loam and sandy loam with sandy loam being dominant. Loam is more likely to occur in the lower parts of ridges and in the surficial layers of tills to a depth of $1 \mathrm{~m}$. The material comprising the Icelandic drumlin is characterised by its poorly-sorted character and the associated broad range of particle sizes. The overall grain-size distributions are coarser than the Ruopiškiai MSGL and are classified as glacigenic pebble-sand whose composition remains almost the same in the upper part of till. The geometrical differences of the investigated subglacial bedforms are associated with the differences of the underlying surface deposits and their different response to glacigenic processes. For example, the drumlins exposed at Skeiðarárjökull are located in an area formerly characterised by ice-contact fans that were subsequently overridden and drumlinised during the 1991 surge event (Waller et al. 2008). In these circumstances, the well-drained nature of the constituent coarse-grained sands and gravels results in these areas acting as 'sticky spots' with the fan apices acting as the loci for drumlin formation (Boulton 1987; Piotrowski et al. 2004). The pre-existing surficial deposits therefore exert a strong control on the subsequent development of streamlined bedforms by controlling the effective pressures and the rates of subglacial sediment deformation.

The differences in the orientation and dip of the long axes of the macro clasts and the microfabrics derived from the AMS analyses are a key finding of this study. Presumably differences are unavoidable (Gentoso et al. 2012), but in some test pits in the Ruopiškiai MSGL, they showed a good correlation. In the case of AMS, the recurring NW direction was identified in all pits (see Fig. 8). As to the orientation of the clast macrofabrics, a NW direction was identified in two pits and a $\mathrm{N}$ direction also in two pits (see Fig. 6). The E-W direction determined by AMS in three pits corresponds to the direction of long axes of macro clastic material in two pits. The complicated picture of orientational directions may indicate that the formation of Ruopiškiai MSGL was affected by polyphase deformation with different stress fields occurring at different times. The emergence of the lateral force can be associated with the lateral drag of the glacier in the upper part of the underlying surface (Gaigalas, Marcinkevičius 1982). Alternatively, a number of previous studies have indicated that clast fabrics can vary according to grain size (Kjær, Kruger 1998) and Carr, Rose (2003) concluded that, "particles of different size are rarely orientated consistently in relation to ice flow direction" (p. 1425). The observed differences in the orientations of the macrofabrics and microfabrics may therefore reflect different grain-orientating processes operating at different spatial scales.
The formation of the Ruopiškiai MSGL may have involved two phases of development. The first phase is connected to the relatively rapid advance of the Nevezzis glacier lobe into the Middle Lithuania which generated subglacial flutes orientated $\mathrm{N}-\mathrm{NE}$ and S-SW. The second phase is related with the degradation of Mūša-Lèvuo glacier lobe when its N-S orientated eastern edge receded westward. This circumstance is responsible for the deformation of the fluted subglacial surface by the receding glacier almost perpendicularly. Corroborative evidence for these two phases is provided by the geomorphological and morphometric data of the investigated landforms. The regional topography is generally inclined in WNW direction whereas the relative altitude of the MSGL crests decreases in a NW direction before merging into a plain surface. The ridges are slightly asymmetric, i.e. their western slope is longer and shallower than the shorter and steeper eastern slope. The flat tops of ridges are interspersed with small lanceolate forms, small (up to $1 \mathrm{~m}$ in height) crests (micro forms), which represent the top relicts of smoothed hills. The ridges are also interspersed with small declensions, which join the hollows between the ridges. These negative forms of relief are orientated from NE to SW or from SE to NW. Presumably they were generated by a receding glacier whose margin broke the NE-SW oriented initial fluted surface. Its original fragment is visible $4-8 \mathrm{~km}$ east of Vabalninkas.

Investigation of the Skeiðarárjökull drumlin reveals a less complicated evolution. The orientation and inclination data (see Fig. 11) showed rather variable orientation of macro clastic material in the middle part of the drumlin (N and $\mathrm{NE}$ ) and in its proximal part (SE). The AMS data (see Fig. 12) were identical in both test pits and demonstrated a predominant northern direction. The orientation and inclination data from the proximal part (S2) show the perpendicular character of the stress (from NW to SE the SE direction being the dominant) as distinct from the middle part (S1). The SE direction and inclination presumably imply local recession of the overlying glacier in the direction of the recent inclination of the drumlin surface and towards the submerged depression at the glacier margin. In the upper and lower parts of till units, the micro clastic material is orientated in the same direction and correlates with the drumlin crest direction.

Comparative analysis of the data obtained from the Ruopiškiai and Skeiðarárjökull subglacial bedforms showed that their formation and post-genetic transformations are different. They were both generated in the subglacial environment by the force of a rapidly advancing glacier. However, the subsequent processes were different. The Ruopiškiai MSGL was strongly affected by the recession of the edge of de- 
grading glacier lobe westward whereas the proximal part of the Skeiðarárjökull drumlin was deformed by recession of the degrading glacier.

\section{CONCLUSIONS}

Measurements of the orientation and dip of the long axes of macro clastic material composing the Ruopiškiai MSGL and AMS of micro clastic material showed good correlations. In the case of the AMS microfabric results, the recurring NW direction was identified in all the test pits. Orientation and dip analysis showed a predominant NW direction in two test pits and a $\mathrm{N}$ direction in another two. The orientation and dip data obtained from Skeiðarárjökull showed different orientation of macro clastic material in the middle and proximal parts of the drumlin. The AMS data was identical in both test pits and showed a dominant $\mathrm{N}$ direction. The complicated picture of orientations may indicate a polyphase origin for the Ruopiškiai MSGL associated with different flow directions at different times.

The formation of the Ruopiškiai MSGL and the Vabalninkas MSGLs area involved two distinct phases. The first phase was associated with relatively rapid advance of the Nevèžis glacier lobe into Middle Lithuania forming a fluted topography oriented from N-NE to S-SW. The second phase was associated with the degradation of Mūša-Lèvuo glacier lobe when its N-S orientated eastern edge receded westward.

Investigation of the Skeiðarárjökull drumlin showed that its formation was less complicated. The AMS data shows that the micro particles of the compacted sand underlying till have a steeper $\mathrm{N}$ dip that implies higher velocity of glacier during the surge of 1991 in the interface (shear surface) with the sand. The micro clastic material in the upper and lower parts of the overlying till unit displays identical orientations that are also parallel to the long axis of the drumlin. The orientation and inclination of the AMS data presumably implies local recession of the overlying glacier after the surge event. This retreat followed the dip of the drumlin surface towards the current margin that rests in a depression.

Investigation and comparative analysis of the subglacial bedforms in Lithuania and Iceland show that their formation and post-genetic transformations were different. The crucial role in their initial stage of formation was played by the force of advancing glacier in the subglacial environment. Yet the subsequent forming processes were different. The westward shift of the degrading glacier lobe played an important role in the formation of Ruopiškiai MSGLs whereas deformation of the proximal part of Skeiðarárjökull drumlin occurred due to retreat of the degrading glacier.

\section{ACKNOWLEDGEMENTS}

Authors are grateful to Professor Vitālijs Zelčs (Rīga) and Professor Petras Šinkūnas (Vilnius) for constructive remarks that substantially helped to improve the manuscript. This research was performed within the framework of project No. MIP-11149 funded by the Research Council of Lithuania, and was partly supported by the project "Geosystems", financed by the Ministry of Education and Science.

\section{REFERENCES}

Baltrūnas, V., Šinkūnas, P., Karmaza, B., Česnulevičius, A., Šinkūnè, E., 2009. The sedimentology of debris within basal ice, the source of material for the formation of lodgement till: an example from the Russell Glacier, West Greenland. Geologija 51 (1-2), 12-22.

Basalykas, A., 1965. Physical Geography of the Lithuanian SSR, II. Mintis Press, Vilnius, 492 pp. [In Lithuanian with Russian summary].

Benn, D. I., 1994. Fabric shape and the interpretation of sediment ary fabric data. Journal of Sedimentary Research $A 64$ (4), 910-915.

Benn, D. I., Evans, D. J. A., 1998. Glaciers and Glaciation. London, Arnold, $734 \mathrm{pp}$.

Bennett, M. R., Glasser, N. F., 2009. In Glacial Geology. Ice Sheets and Landforms. Wiley-Blackwell, UK, 268-285.

Björnsson, H., 1998: Hydrological characteristics of the drainage system beneath a surging glacier. Nature 395, 771-774.

Blott, S. J., Pye, K. 2001. GRADISTAT: a grain size distribution and statistics package for the analysis of unconsolidated sediments. Earth Surface Processes and Landforms 26, 1237-1248.

Boulton, G. S., 1987. A theory of drumlin formation by subglacial sediment deformation. In J. Menzies, J. Rose (eds), Drumlin symposium, Rotterdam, Balkema, 2580.

Brodzikowski, K., van Loon, A. J., 1991. Glacigenic Sediments. Collection Development in Sedimentology 49, Amsterdam, Elsevier, 674 pp.

Carr, S. J., Rose, J., 2003. Till fabric patterns and significance: particle response to subglacial stress. Quaternary Science Reviews 22 (14), 1415-1426.

Clark, C. D., 1993. Mega-scale glacial lineations and cross-cutting ice-flow landforms. Earth Surface Processes and Landforms 18 (1), 1-29.

Clark, C. D., Hughes, A. L. C., Greenwood, S. L., Spagnolo, M., Ng, F. S. L., 2009. Size and shape characteristics of drumlins, derived from a large sample, and associated scaling laws. Quaternary Science Reviews $28(7-8), 677-692$.

Čepulyte, V., 1956. On the problem of relief morphogenesis in Lithuanian SSR. Proceedings of Academy of Sciences of Lithuanian SSR, B, I, 77-93. [In Lithuanian with Russian summary]. 
Doss, B., 1910. Über das Vorkommen einer Endmoräne, sowie Drumlins, Åsar und Bänderton im nördlichen Lithauen. Zentralblatt für Mineralogie, Geologie und Paläontolologie, Abteilung B. Geologie und Paläontologie 22, 723-731.

Evans, D. J. A., 2009. Controlled moraines: origins, characteristics and palaeoglaciological implications. Quaternary Science Reviews 28 (3-4), 183-208.

Gaigalas, A., 1979. Glaciosedimentation Cycles of the Lithuanian Pleistocene. Vilnius, Mokslas, 98 pp. [In Russian with English summary].

Gaigalas. A., 1995. Grain size classification of clastic rocks and deposits. Vilnius University Press, Vilnius, 25 pp. [In Lithuanian].

Gaigalas, A., 1997. Drumlins and flutings in Lithuania. Geografija 33, 18-23. [In Lithuanian with English summary].

Gaigalas, A., Marcinkevičius, V., 1982. Bedded structure and genesis of forms of hollow-ridge glacial relief in North Lithuania. Geologija 3, 69-79. [In Russian with English summary].

Gaigalas, A., Mikutienė, L., Vaitiekūnas, S., 1971. Influence of the bed-rock surface on the formation of glacial relief. In V. Gudelis (Ed.), Structure and morphogenesis of the Middle Lithuanian morainic plain. Vilnius, Mintis Publishers, 18-27 [in Russian with Lithuanian summary].

Gentoso, M. J., Evenson, E. B., Kodama, K. P., Iverson, N. R., Alley, R. B., Berti, C. and Kozliwski, A., 2012. Exploring till bed kinematics usin AMS magnetic fabrics and pebble fabrics: the Weedsport drumlin field. Boreas 41, New York State, USA., 31-41.

Głębicki, P., Marks, L., 2009. The origin of drumlins at Zbojno, Central Poland. Geologija 51, No. 3-4 (6768), 131-138.

Guobyte, R., 2002. Lithuanian surface: geology, geomorphology and deglaciation. Abstract of doctoral dissertation. Vilnius University, $31 \mathrm{pp}$.

Hausen, H., 1913. Über die Entwicklung der Oberflächenformen in den russischen Ostseelandern und angrenzenden Gouvernements in der Quartärzeit. Fennia 34 (3), 142 pp.

Jelinek, V., 1977. The statistical theory of measuring anisotropy of magnetic susceptibility of rocks and its application. Brno, Geofyzika, 88 pp.

Johnson, M. D., Schomacker, A., Benediktsson, Í. Ö., Geiger, A. J., Ferguson, A, Ingólfsson, Ó., 2010. Active drumlin field revealed at the margin of Múlajökull, Iceland: A surge-type glacier. Geology 38 (10), 943-946.

Kamb, B. 1987: Glacier surge mechanism based on linked cavity configuration of the basal water conduit system. Journal of Geophysical Research 92, 9083-9100.

Kamb, B., Raymond, C. F., Harrison, W. D., Engelhardt, H., Echelmeyer, K. A., Humphrey, N., Brugman, M. M., Pfeffer, T. 1985: Glacier surge mechanism: 1982-1983 surge of Variegated Glacier, Alaska. Science 227, 469-479.

King, E. C., Hindmarsh, R. C. A., Stokes, C. R., 2009. Formation of mega-scale lineations observed beneath a West Antarctic ice stream. Nature Geoscience 2, 585-588.
Kjær, K. H., Kruger, J., 1998. Does clast size influence clast strength? Journal of Sedimentary Research, Section A 68 (5), 746-749.

Knight, J., 2010 a. Drumlins and the dynamics of the subglacial environment. Sedimentary Geology 232 (3-4), 91-97.

Knight, J., 2010 b. Basin-scale patterns of subglacial sediment mobility: Implications for glaciological inversion modelling. Sedimentary Geology 232 (3-4), 145-160.

Krüger, J., 1987. Relation of drumlin shape and distribution to drumlin stratigraphy and glacial history, Mýrdalsjökull, Iceland. In Menzies, J., Rose, J (eds), Drumlin symposium, Rotterdam, Balkema, 257-266.

Matveyev, A. V., Gurski, B. N., Levitskaya, R. I., 1988. Relief of Belarus. Minsk, Universitetskoye, 320 pp. [In Russian].

Menzies, J., 1984. Drumlins - A Bibliography. Geo Books, Norwich, $117 \mathrm{pp}$.

Mikalauskas, A., Mikutienė, L., 1971. Glaciofluvial deposits. In V. Gudelis (Ed.), Structure and morphogenesis of the Middle Lithuanian morainic plain. Vilnius, Mintis Publishers, 92-124. [In Russian with Lithuanian summary].

Møller, P., 2010. Melt-out till and ribbed moraine formation, a case study from south Sweden. Sedimentary Geology, 232 (3-4), 161-180.

Mortensen, H., 1924. Beiträge zur Entwicklung der glazialen Morphologie Litauens. Geologisches Archiven Bd. III, H. 1/2, 1-93.

Muller, F. H., 1974. Origin of Drumlins. In: D.R. Coates (Ed.). Glacial Geomorphology. Fitfth Annual Symposia Series, Binghamton, 187-204.

Pálsson, S., Vigfússon, G. H., 1996. Gagnasafn aurburðarmaelinga 1963-1995. Report OS-96032/VOD-05 B. Orkustofnun (National Energy Authorities), Reykjavk, Iceland.

Pálsson, S., Zóphóniasson, S., Sigursson, O., Kristmannsdottir, H., Ajalsteinsson, H. 1992: Skeiðararhlaup og framlaup Skeiðararjo“kuls 1991. Report OS-92035/ VOD-09 B. Orkustofnun (National Energy Authorities), Reykjavı'k, Iceland, 33 pp.

Piotrowski, J. A., Larsen, N. K., Junge, F. W., 2004. Reflections on soft subglacial beds as a mosaic of deforming and stable spots. Quaternary Science Reviews 23, 993-1000.

Rabassa, J., 1987. Drumlins and drumlinoid forms in northern James Ross Island, Antarctic Peninsula. In Menzies, J., Rose, J. (eds), Drumlin symposium, Rotterdam, Balkema, 267-288.

Rattas, M., Kalm, V., 2001. Lithostratigrphy and distribution of tills in the Saadjärve drumlin field, East-central Estonia. Proceedings of the Estonian Academy of Sciences, Geology 50 (1), 24-42.

Russell, A. J., Knight, P. G., Van Dijk, T. A. G. P., 2001. Glacier surging as a control on the development of proglacial fluvial landforms and deposits, Skeiðararsandur, Iceland. Global and Planetary Change 28, 163-174.

Schomacker, A., Krüger, J., Kjær, K. H., 2006. Ice-cored drumlins at the surge-type glacier Brúarjökull, Iceland: 
A transitional-state landform. Journal of Quaternary Science 21, 85-93, doi: 10.1002/jqs.949.

Shaw, J., 2002. The meltwater hypothesis for subglacial bedforms. Quaternary International 90, 5-22.

Shaw, J., 2010. In defence of the meltwater (megaflood) hypothesis for the formation of subglacial bedform fields. Journal Quaternary Science 25, 249-260.

Sigurðsson, O. 1998: Glacier variations in Iceland 1930 1995 , from the database from the Iceland Glaciological Society. Jökull 45, 3-25.

Smith, A. M., Murray, T., Nicholls, K. W., Makinson, K., Aðalgeirsdóttir, G., Behar, A. E., Vaughan, D. G., 2007. Rapid erosion, drumlin formation, and changing hydrology beneath an Antarctic ice stream. Geology, 35, 127-130, doi: 10.1130/G23036A.1.

Spagnolo, M., Clark C. D., Hughes, A. C. L., Dunlop, P., Stokes, C. R., 2010. The planar shape of drumlins. Sedimentary Geology, 232(3-4), 119-129.

Van der Meer, J. J. M., 1983, A recent drumlin with fl uted surface in the Swiss Alps. In Evenson, E. B., et al., (eds), Tills and related deposits, Rotterdam, Balkema, 105-110.

Van Dijk, T. A. G. P., 2000 a: Fluvial geomorphology and sedimentology in front of a surge-type glacier, Skeijara' rjo“" kull, Iceland. In Russell, A. J., Marren, P. M. (eds), Iceland 2000, Modern Processes and Past Environments, 115-117, Department of Geography Occasional Papers Series 21, Keele University.
Van Dijk, T. A. G. P., 2000 b. The proglacial fluvial landsystem as a diagnostic criterion for surge-type glaciers. In Russell, A. J., Marren, P. M. (eds). Modern and Ancient Ice-Marginal Landsystems, 76-78, Department of Geography Occasional Papers Series 22, Keele University.

Van Dijk, T. A. G. P., 2002. Glacier Surges as a Control on the Development of Proglacial Fluvial Landforms and Deposits. Ph.D. dissertation, Keele University, 342 pp. Van Dijk, T. A. G. P., Sigurðsson, O., 2002. Surge-related floods at Skeiðararjökull Glacier, Iceland: implications for ice-marginal outwash deposits. In Snorrason, A., Finnsdottir, H. P., Moss, M. (eds): The Extremes of the Extremes: Extraordinary Floods, IAHS Special Publication 271. Reykjavık, Iceland, 193-198.

Waller, R. I., Van Dijk, T. A. G. P., Knudsen, O., 2008. Subglacial bedforms and conditions associated with the 1991 surge of Skeiðararjokull, Iceland. Boreas 37, 179-194.

Woodcock, N. H., 1977. Specification of fabric shapes using an eigenvalue method. Geological Society of America Bulletin 88, 1231-1236.

Zelčs, V., Dreimanis, A., 1997. Morphology, internal structure and genesis of the Burtnieks drumlin field, Northern Vidzeme, Latvia. Sedimentary Geology, Special Issue 111 (1-4), 73-90.

Zelčs, V., Markots, A., 2004. Deglaciation history of Latvia. In J. Ehlers, P. L. Gibbard (eds), Quaternary Glaciations - Extent and Chronology, Part I: Europe. Amsterdam, Elsevier, 225-243. 